\title{
SOUTH AFRICAN RUST FUNGI, III.
} by

\author{
E. M. Doidge.
}

\author{
[ The first paper of this series, entitled "A Preliminary \\ Study of the South African Rust Fungi" constituted Part Ia \\ of Vol. 2 of Bothalia (1927). South African Rust Fungi II \\ appeared in Vol. 2 Part 2 (1928)].
}

\section{Aecidium Burtt-Davyi nov. spec.}

Aecidiis foliicolis et petiolicolis, matricem incrassatis, plerumque dense confertis, cylindraceis, usque $2 \mathrm{~mm}$. longis, 300-400 $\mu$ latis, pallide flavis, primo clausis dein apertis margine erecto vix lacerato ; cellulis peridie arctissime conjunctis, irregularibus, $25-42.5 \times$ 10-20 $\mu$, pariete exteriore striato $8-15 \mu$ crasso, interiore striato-verrucoso $4-5 \mu$ crasso ; sporis subglobosis, ovatis, ellipsoideis v. oblongis, saepe irregularibus et angulatis, subtilissime verruculosis, $21-43 \times 16-22 \cdot 5 \mu$, episporio ubique $2-2 \cdot 5 \mu$ crasso, poris germinationis obscuris.

Hab. in foliis petiolisque Acaciae stoloniferae Burch., Christiana, leg. Burtt Davy, 1973 et 5581 .

This may possibly be the aecidial stage of Ravenelia modesta (q.v.) which occurs on the same host, but the aecidium and the teleuto-form were collected in widely separated localities and no connection between the two forms has yet been established.

Aecidium Dinteri nov. spec.

Pycnidiis minutis, superficialibus, inter aecidia distributis, applanato-hemisphericis, melleo-brunneis, $50-75 \mu$ diam.

Aecidiis ramicolis et petiolicolis, ramulos incrassatos et uncinatos plus minus contortos dense aequaliterque distributis, longe exsertis, tubulosis, $2 \cdot 5-4 \mu$ altis, 250-300 $\mu$ latis, pallide flavo-brunneis, diu clausis, tandem apertis, margine pallidiore, leniter recurvato, denticulato; cellulis peridie arctissime conjunctis, quoad formam valde variabilis, saepe rectangularibus $\mathrm{v}$. irregulariter rhomboideis, $25-\mathbf{4} 3 \times 15-20 \mu$, pariete exteriore striato, 12-15 $\mu$ crasso, interiore striato-verrucosa $3 \cdot 5-5 \mu$ crảsso. Sporis irregularibus plerumque angulato-globosis oblongis $\mathrm{v}$. ellipsoideis, $25-32.5 \times 17 \cdot 5-22.5 \mu$, dense minuteque verruculosis, subhyalinis; episporio $2 \cdot 5-3 \mu$ crasso, poris germinationis sparsis (usque 8) praedito.

Hab. in ramis petiolisque Acaciae urcinatie Engl., Otjihavera-Okapuka, S.W. Africa, leg. Dinter 3488 (ex. Herb. Marloth) 26686.

\section{Aecidium litakunensis nov. spec.}

Pycnidiis inter aecidiis sparsis, melleis, applanato-hemisphericis, $60-100 \mu$ diam.

Aecidiis foliicolis et ramicolis ; in foliis petiolisque gallas subglobosas usque oblongas, plus minus flexuosas et distortas, magnitudine variabiles, $2-4 \mathrm{~cm}$. longas, $5-15 \mathrm{~mm}$. crassas formantibus, dense confertis, cylindraceis, usque $1.5 \mathrm{~mm}$. longis, $350-500 \mu$ latis, flavidis v. flavo-brunneis, diu clausis; cellulis peridie irregularibus, $20-37 \cdot 5 \times 7 \cdot 5-17 \cdot 5 \mu$, pariete exteriore striato $12-15 \mu$ crasso, interiore striato-verrucoso $3-5 \mu$ crasso. Sporis globosis, ovatis, ellipsoideis v. oblongis, saepe irregularibus et angulatis, verruculosis, pallide flavidis v. subhyalinis, $22-30 \times 17-22 \mu$, episporio ubique $1.5-2 \mu$ crasso, poris germinationis obscuris.

$\mathrm{Hab}$. in foliis Acaciae litakunensis Burch., inter Rustenburg et Northam, leg. Scott, 27294 ; Bechuanaland leg. Burtt Davy, 2443. 
Aecidium Moggii nov. spec.

Pycnidiis amphigenis sed plerumque epiphyllis, copiose evolutis, inter aecidia distributis vel per magnam folii partem aequaliter dispositis, ex flavidis tandem nigrescentibus, $90-130 \mu$ diam.

Aecidiis hypophyllis, singulis subinde epiphyllis, plerumque per totam folii superficiem dense aequaliterque distributis, cupulatis, $200-250 \mu$ diam., margine laciniato ; cellulis peridie fere quadraticis usque rhomboideis, $20-35 \times 10-20 \mu$, pariete exteriore striato 5-6 $\mu$ crasso, interiore verrucoso 3-5 $\mu$ crasso. Sporis argulato-globosis, oblongis $\mathrm{v}$. late ellipsoideis, minutissime verruculosis, subhyalinis, $17-22.5 \times 15-20 \mu$, episporio $1.5-2 \mu$ crasso.

Hab. in foliis Senecionis coronati Harv., Pretoria, leg. Mogg, 23636.

\section{Aecidium tetragoniae nov. spec.}

Pycnidiis amphigenis, inter aecidia copiose sparsis, melleis dein atro-brunneis, $120-180 \mu$ diam.

Aecidiis amphigenis, totam folii superficiem vel magnam ejus partem dense aequaliterque obtegentibus, diu hemispherico-clausis, tandem apertis cupulatis, 300-400 $\mu$ diam., margine albido laciniato mox evanescente ; cellulis peridie laxe conjunctis, irregularibus, $27-42 \times$ 15-25 $\mu$, pariete exteriore striato $5-8 \mu$ crasso, interiore verrucoso $2-3 \mu$ crasso. Sporis sub-globosis, oblongis, ellipsoideis vel ovatis, plerumque angulatis, $20-32.5 \times 15-20 \mu$; episporio $2 \cdot 5-5 \mu$ crasso, dense minuteque verruculoso.

Hab. in foliis Tetragoniae arbusculae Fenzl., Fauresmith, leg. Henrici, 25892.

\section{Masseeëlla flueggeae Syd.}

in Ann. Myc. 26 (1928) 424.

Syn. Uredo brideliae (P. Henn. et Evans) Doidge in Bothalia 2 (1927) 193.

Aecidium brideliae P. Henn. et Evans in Engl. Bot. Jahrb. 41 (1908) 272 ; Syd. Monogr. Ured. 4 (1924) 186.

Uredo-sori hypophyllous, on small leaf spots which may be indistinct, or yellow to yellow-brown, irregularly scattered or in groups of $2-8$, long covered by the discoloured, yellow-brown epidermis, very minute, $200-350 \mu$ diam. Uredospores subglobose, ovate or

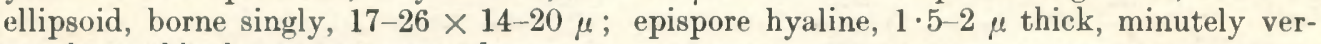
ruculose-echinulate, germ pores obsçure.

Teleuto-sori epiphyllous-very rarely a single one occurs on the under side of the leaf-deeply immersed, in small or larger groups, or even solitary, minute; the spores protrude from the sori in filiform columns $1-2.5 \mathrm{~mm}$. long and $50-90 \mu$ broad, these are usually curved and become dark brown when dry. Teleutospores ovate or ellipsoid, often slightly angular, 1-celled, smooth, deep yellow or golden yellow, embedded in a mucous mass, $22-30 \times 15-21 \mu$; epispore about $3 \mu$ thick with a distinct apical germ pore.

Hab. on leaves of Fluggea virosa (Roxb.) Baill. (= Fluggea microcarpa Blume) near Nelspruit, Burtt Davy, 77 ; Nelspruit, Liebenberg, 25968 ; Schagen, Liebenberg, 26359.

In Bothalia (loc. cit.) it was pointed out that number 77 was a uredo-form; more recently the teleuto-stage has been collected by Liebenberg, and it agrees in every detail with the fungus described by Sydow on Fluggea virosa from the Philippines.

\section{Puccinia bylianum Dippenaar.}

in the South African Journ. Sci. 28 (1931) 288.

Syn. Aecidium bylianum Syd. in Ann. Myc. 22 (1924) 236 ; Bothalia 2 (1927) 172.

Aecidia hypophyllous or caulicolous, developing on thickened and sometimes distorted parts of the host plant, sub-seriate or in densely crowded, elongated groups 1-2 cm. long (fide Sydow, amphigenous, chiefly hypophyllous, on yellow leaf spots, closely crowded in 
groups 3-8 mm. diam.) immersed, cupulate, 250-300 $\mu$ diam., margin erect, white, lacerate. Cells of the peridium firmly compacted, rhomboid, $20-30 \times 10-16 \mu$; outer wall striate, 6-10 $\mu$ thick, inner verrucose $3-5 \mu$ thick. Spores angular-globose, subhyaline, 10-18 $\mu$ diam., epispore very delicately verruculose, about $1 \mu$ thick.

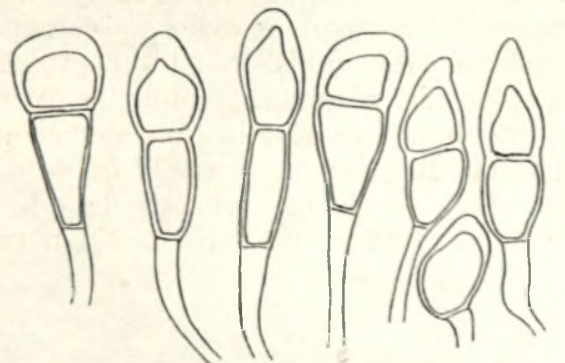

Fig. 1.-Puccinia bylianum, teleutospores.

Teleuto-sori caulicolous, rarely on the leaves, scattered or in groups, often developing between the aecidia, long covered by the raised epidermis, which finally splits longitudinally, oblong, about $\frac{1}{2} \mathrm{~mm}$. long, sometimes becoming confluent and up to $4 \mathrm{~mm}$. long, black. Teleuto-spores oblong, ellipsoid or subclavate, $35-52.5 \times 12 \cdot 5-22 \cdot 5 \mu$, light brown, darker at the apex ; apex rounded, truncate or obtusely acuminate, often oblique, attenuate at the base, constricted at the septum; epispore smooth, 1.5-2 $\mu$ thick, thickened at the apex up to $8 \mu$; pedicel persistent, up to $42 \mu$ long, subhyaline or light brown, 5-6 $\mu$ thick. Mesospores fairly numerous, elipsoid to subclavate, $25-33 \times 15-17 \cdot 5 \mu$; epispore similar to that of the teleutospores. An occasional 3-septate spore was seen.

Hab. on leaves and stems of Senecio Burchellii DC., Bloemfontein, Potts, 24875 (Grey. Univ. Coll. No. 8017) ; I. Pretoria, Fuller, 15018.

In Bothalia 2 (1927) 171, the aecidial stage (No. 15018) was recorded as Aecidium incertum Syd. on Senecio laevigatus Thun. On comparison, the host of this number proves to be the closely similar species Senecio Burchellii, and the aecidium is identical with that of the plant on which teleuto-sori were found.

The aecidium closely resembles Aecidium incertum Syd., which was first described on Senecio napifolius; no teleutosori have yet been found on the latter host, so that it is impossible to say whether Aecidium incertum Syd. is a synonym for Puccinia bylianum.

Although the teleutospores of the Orange Free State specimen are somewhat smaller, there can be no doubt that this is the rust found in the winter rainfall area, and described by Dippenaar as occurring on Senecio spp., Senecio littoreus, S. pinnulatus, S. vulgaris and S. bipinnatifuda from Ceres, Hopefield, Knysna and Stellenbosch.

This species differs widely from Puccinia pentactina described as occurring on Senecio pentactinus [Bothalia 2 (1928) 473].

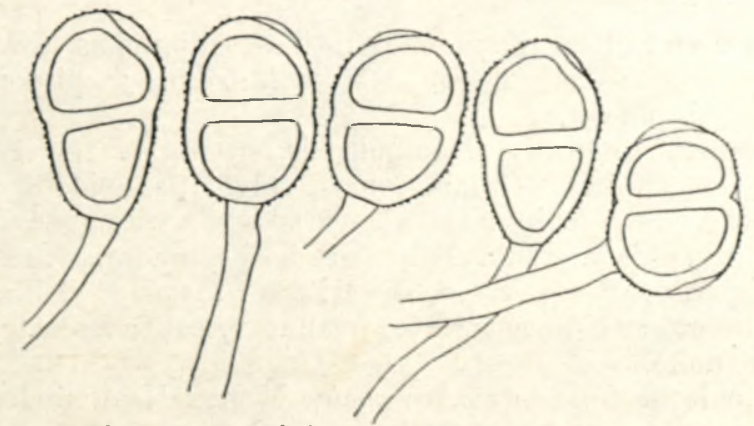

Fig. 2.-Puccinia pentactina, teleutospores. 
Puccinia Liebenbergii nov. spec.

Aecidiis hypophyllis, maculis brunneolis 1-2 mm. diam. insidentibus, 3-7 in centro macularum aggregatis, cupulatis, 200-250 $\mu$ diam., margine albido reflexo laciniato ; cellulis peridie laxiuscule conjunctis, rhomboideis, $20-25 \times 15-18 \mu$, pariete exteriore striato, $2-4 \mu$ crasso, interiore verrucoso, $2-5 \mu$ crasso. Aecidiosporis angulato-globosis v. ellipsoideis, dense et subtilissime verruculosis, subhyalinis, 12-20 $11-15 \mu$ episporio $1 \mu$ crasso.

Soris uredosporiferis amphigenis, plerumque epiphyllis, per totam folii superficiem plus minusve dense sparsis, interdum circa aecidia annula efficientibus, minutis, rotundatis, usque $\frac{1}{2} \mathrm{~mm}$. diam., epidermide bullata diu tectis, dein poro rotundo centrali apertis, cinnamomeo-brunneis. Uredosporis subglobosis v. ovatis, flavo-brunneolis, ubique aequaliter et sat valide aculeatis, $20-25 \times 20-21 \mu$, episporio $1.5-2$ u crasso, poris germinationis obscuris.

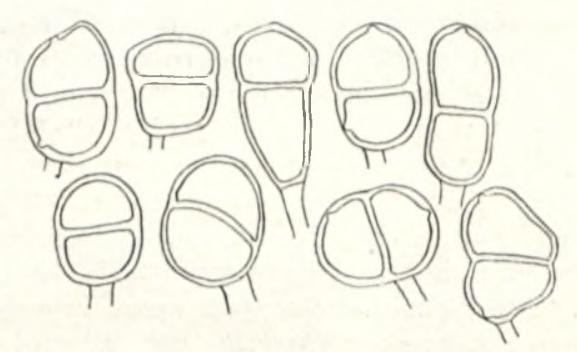

Fig. 3.-Puccinia Liebenbergii, teleutospores.

Soris teleutosporiferis conformibus, atro-brunneis, vel teleutosporis in soris uredosporiferis immixtis. Teleutosporis ellipsoideis, sub-globosis v. irregularibus, levibus, brunneis, $27 \cdot 5-40 \times 20-27 \cdot 5 \mu$, apice plerumque rotundatis rarius applanatis, medio leniter constrictis, basi plerumque rotundatis interdum attenuatis ; episporio $1.5 \mu$ crasso, ad apicem haud incrassato; pedicello hyalino, deciduo, teleutosporam subaequante, verticale $\mathrm{v}$. oblique, nonnunquam transverse inserto.

Hab. in foliis Sonchi sp., Schagen, leg. Liebenberg, 26176.

Puccinia gnidiae nov. spec.

Uredosporis in soris teleutosporiferis immixtis, late ellipsoideis, ovatis v. subglobosis, brunneis, subtiliter denseque verruculosis, $25-30 \times 22 \cdot 5-25 \mu$; episporio $2 \cdot 5-3 \mu$ crasso, poris germ. ca $4-7$ sparsis praeditis.

Soris teleutosporiferis caulicolis v. amphigenis, sparsis v. aggregatis, rotundatis v. ellipticis, interdum confluentibus, $\frac{1}{2}-3 \mathrm{~mm}$. longis, pulvinatis, epidermide lacerata cinctis. Teleutosporis sub-globosis, late ellipsoideis v. ovatis, levibus, castaneo-brunneis, $30-40 \times$ $25-30 \mu$, apice late rotundatis interdum compressis, basi rotundatis $\mathrm{v}$. subattenuatis, medio vix constrictis ; episporio $2 \cdot 5-4 \mu$ crasso, apice leniter (usque $8 \mu$ ) incrassato ; pedicello persistente, valido, interdum oblique inserto, hyalino v. subflavescente, $7 \cdot 5-10 \mu$ crasso, lumine haud raro fere nullo. 10083.

Hab. in caulis foliisque Gnidiae macrocephalae Meisn., Kaalfontein, leg. Pole Evans, 
The stems of the host plant showed indications of the occurrence of an aecidium earlier in the season.

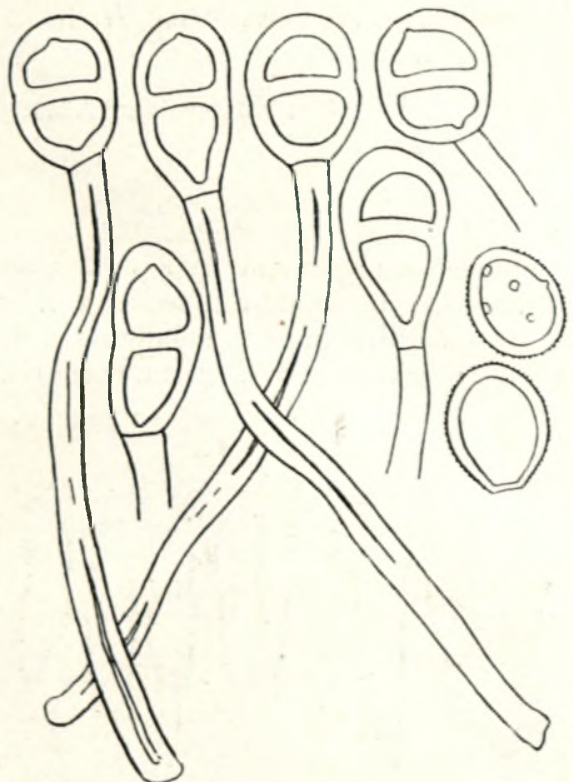

Fig. 4.-Puccinia gnidiae, teleutospores and uredospores.

Mesospores were occasionally seen ; they were ovate, $30-33 \times 25-27 \cdot 5 \mu$, with characters similar to those of the teleutospores. The upper loculus of the teleutospore is often compressed, directly (making the apex almost flat) or obliquely.

\section{Puccinia iridis (DC.) Wallr.}

in Rabh. Krypt. Fl. ed. I (1844) 23 ; Syd. in Monogr. Ured. 1 (1904) 598.

Uredo-sori amphigenous, scattered or subgregarious, round, oblong or elongated, long covered by the epidermis, which at length splits and remains partially veiling the pulverulent sorus, up to $2 \mathrm{~mm}$. long, rusty brown. Uredospores globose, subglobose, ellipsoid or ovate, ochraceous, $20-35 \times 16-26 \mu$; epispore rather coarsely echinulate, $1.5-2 \mathrm{~mm}$. thick, slightly thicker $(2 \cdot 5 \mu)$ at the base, germ pores $2-3$ equatorial, rather conspicuous, papillate.

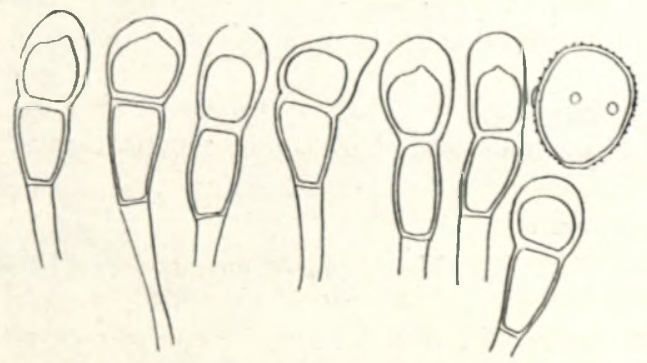

Fig. 5.-Puccinia iridis, teleutospores and one uredospore.

Teleuto-sori hypophyllous, scattered, sometimes confluent, sometimes developing between the uredo-sori, linear or striiform, early becoming naked, black. Teleutospores clavate or oblong, rounded, acuminate or truncate at the apex, slightly constricted at the septum, usually attenuate at the base, light golden brown, darker at the apex, $30-52 \times$ 
14-22 $\mu$; epispore smooth, delicate, about $1 \mu$ thick in the lower loculus, up to $2 \mu$ thick in the upper, very much thickened, up to $14 \mu$, at the apex; pedicel tinted brown, persistent, as long as the spore or shorter. The loculi separate readily at the septum.

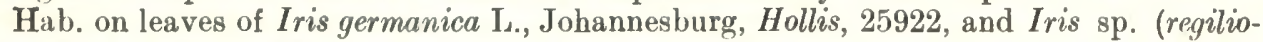
cyclus) Johannesburg Hingst 30142.

This rust, which is widely distributed in Europe and America, has only recently made its appearance in gardens in Johannesburg.

\section{Puccinia caricis-cernuae nov. spec.}

Soris uredosporiferis amphigenis, plerumque hypophyllis, sparsis v. gregariis, oblongis v. linearibus, usque $3 \mathrm{~mm}$. longis, epidermide diu tectis, tandem longitudinaliter apertis, cinnamomeis; Uredosporis ovatis, ellipsoideis v. subglobosis, dilute brunneis, echinulatis, $20-25 \times 16-19 \mu$. episporio $2-2.5 \mu$ crasso, poris germ. obscuris.

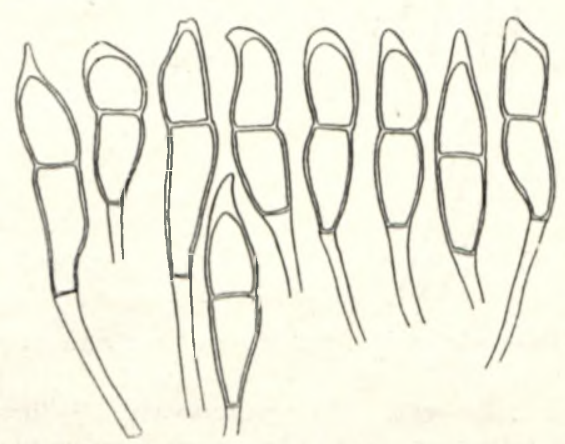

Fig. 6.-Puccinia caricis-cernuae, teleutospores.

Soris teleutosporiferis amphigenis, plerumque hypophyllis, maculis nullis $\mathrm{v}$. indeterminatis flavis insidentibus, sparsis v. gregariis, oblongis v. linearibus, saepe in strias longas (usque $6 \mathrm{~mm}$.) confluentibus, diu epidermide plumbea tectis, pulvinatis. Teleutosporis clavatis v. fusoideo-clavatis, apice rotundatis v. conico-angustatis, saepe oblique productis, nonnunquam subtruncatis, medio leniter constrictis, basi attenuatis, levibus, pallide brunneolis, sursum saturatioribus, $37 \cdot 5-62 \cdot 5 \times 12 \cdot 5-9 \mu$; episporio ca. $1 \mu$ crasso, apice leniter $(2 \cdot 5-9 \mu)$ incrassato; pedicello brunneolo, persistente, usque $48 \mu$ longo, 4-5 $\mu$ crasso.

Hab. in foliis Caricis cernuae Boott. var. austro-africanae Kuk., Pelindaba, leg. Doidge et Bottomley, 29873 ; Skinner's Court, leg. Doidge et Bottomley, 23444.

Puccinia pegleriana nov. nom.

Syn. Puccinia cyperi-tagetiformis (P. Henn.) Kern var. africana Doidge in Bothalia 2 (1927) 116.

The South African fungus differs from Puccinia cyperi-tagetiformis (P. Henn.) Kern (Mycologia XI, 1919, p. 138) in several particulars; the uredospores are somewhat larger and have a much thicker wall, and the teleutospores are considerably longer. $P$. cyperitagetiformis is not represented in the Cryptogamic Herbarium at Pretoria and has not been compared with the South African material, but in view of the distinct differences in the descriptions of both uredo- and teleutospores, it is considered advisable to regard this as a distinct species and not as a variety. 
Puccinia Morganae nov. spec.

Soris teleutosporiferis hypophyllis, maculis flavidis $\mathrm{v}$. brunneolis effusis saepe insidentibus, minutis, rotundatis v. ellipticis, usque $0.4 \mathrm{~mm}$. diam., sparsis v. irregulariter aggregatis, interdum confertis confluentibusque, pulvinatis, diutius tectis, demum epidermide rupta cinctis v. semivelatis, ochraceo-brunneis. Teleutosporis plerumque clavatis v. oblongoclavatis, interdum fusiformis, rarissime 2 -septatis, apice rotundatis, recte v. oblique conicoattenuatis, rarius truncatis, subhyalinis v. dilutissime flavo-brunneolis, $37 \cdot 5-55 \times 12 \cdot 5-$ $15 \mu$, rarius usque $17 \mu$ latis ; episporio leve, tenue, usque $1 \mu$ crasso, apice leniter (usque $3 \mu$ ) incrassato; pedicello subhyalino persistenti, usque $35 \mu$ longo.

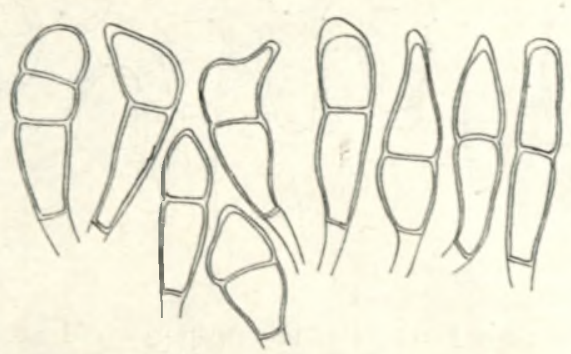

Fig. 7.-Puccinia Morganae, teleutospores.

Hab. in foliis Cyperi albostriati Schrad. in silvis Xumeni, prope Donnybrook, leg. Morgan et Doidge, 29985.

This species differs widely from Puccinia cyperi-fastigiati Doidge and $P$. pegleriana (Bothalia 2, 1928, p. 473; and 2, 1927, p. 117). Teleutospores of the former species are illustrated for comparison; for form of the teleutospores of $P$. pegleriana see Bothalia, loc. cit.

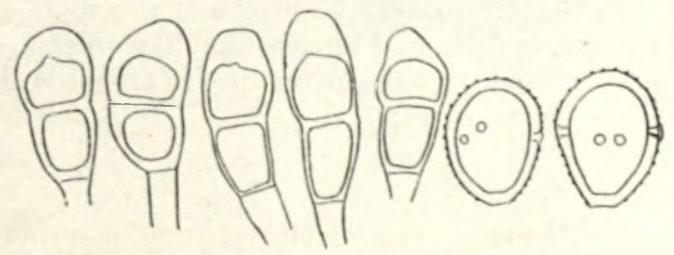

Fig. 8.-Puccinia cyperi-fastigiati, teleutospores and uredospores.

\section{Puccinia fuirenella nov. spec.}

Soris uredosporiferis sine maculis, plerumque hypophyllis, rarius epiphyllis, linearibus, minutis, usque $1 \mathrm{~mm}$. longis, primo epidermide tectis, brunneis. Uredosporis late ellipsoideis, globosis $\mathrm{v}$. ovatis, brunneis, $25-32.5 \times 20-25 \mu$; episporio $2-2.5 \mu$ crasso, remotiuscule echinulato, poris germinationis 2 conspicuis papillatis equatorialibus praeditis.

Soris teleutosporiferis conformibus. Teleutosporis longe clavatis v. lanceolatis, levibus, diluto aureo-brunneis, apice plerumque pallidioribus, rotundatis truncatis v. conicis, nonnunquam obliquis, rarissime dentibus 2 coronatis, medio leniter constrictis, deorsum in pedicellum attenuatis. $42-72.5 \times 17 \cdot 5-22.5 \mu$; episporio $1-2.5 \mu \mathrm{crasso}$, ad apicem valde incrassato usque $13 \mu$; pedicello subhyalino, usque $40 \mu$ longo, apice 8-10 $\mu$ crasso, deorsum attenuatis.

Hab. in foliis vaginisque Fuirenae pubescentis (Lam.) Kunth., Donkerpoort, leg. Doidge et Bottomley, 29977. 
The uredo-form also occurs on :-

Fuirena coerulescens Steud., Maritzburg, Pole Evans, 1444.

Fuirena pubescens (Lam.) Kunth, Nelspruit, Liebenberg, 26074.

Fuirena chlorocarpa Ridley, Xumeni Forest, Donnybrook, Morgan and Dvidye, 29823 ; Donkerpoort, Doilge and Bottonl y, 29983.

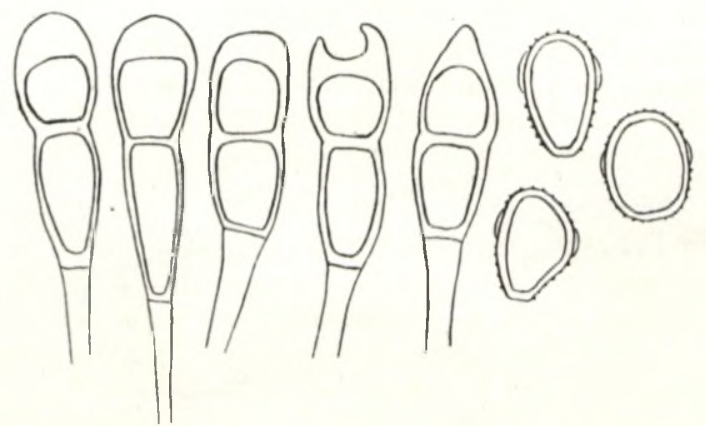

Fig. 9.-Puccinia fuirenella, teleutospores and uredospores.

The uredo on $F$. coerulescens was recorded under the name Uredo Fuirenae P. Henn. in Bothalia 2 (1927), p. 198. Uredo Fuirenae P. Henn. was originally described on Fuirena umbellata from Brazil, and has been shown by Kern, Ciferri and Thurston in Ann. Mye. 31 (1933), p. 13, to be the uredo-form of Puccinia fuirenicola Arth. A portion of the type collection (Mycoflora Domingensis exsiccata 117) of this rust has been examined; the uredospores resemble those of Puccinia fuirenella, but the teleutospores differ in several particulars from those of the South African rust. The original description reads " teliospores cylindric or ellipsoid, constricted at septum, rounded or somewhat pointed above and usually narrowed below; wall cinnamon brown, $1 \cdot 5-2 \mu$; upper cell usually darker and thickened at the apex, 4-7 $\mu$; pedicel slightly tinted, the length of the spore or less ".

Puccinia fuirenella also differs from P. Fuirenae Cke. [Grevillea 6, p. 137 ; Syd. Monogr. Ured. 1 (1904) 687]; the teleutospores of the latter species are more slender, 11-15 $\mu$ broad, and the uredo-spores have 3-4 germ pores.

\section{Puccinia kyllingicola nov. spec.}

Soris uredosporiferis amphigenis v. calamicolis, plerumque autem hypophyllis, maculis conspicuis rufo-brunneis insidentibus, sparsis $v$. paucis aggregatis, nonnumquam circulariter circa sorum centralem dispositis, ellipticis v. oblongis, $\frac{1}{2}$ to $1 \mathrm{~mm}$. longis, epidermide inflata diu tectis. Uredosporis ovatis, ellipsoideis, subglobosis, subinde angulatis, diu hyalinis v. subhyalinis, tandem flavis $\mathrm{v}$. flavo-brunneolis, $22-32.5 \times 15-20 \mu$; episporio $1.5-2 \mu$ crasso, breviter laxiusculeque echinulato, poris germ. 2, rarius 3-4, equatorialibus praedito.

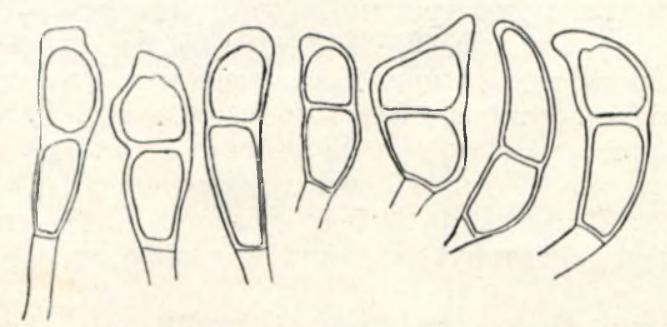

Fig. 10.-Puccinia kyllingicola, teleutospores. 
Soris teleutosporiferis minutis, compactis, epidermide tectis. Teleutosporis oblongis v. clavatis, rectis v. curvatis, levibus, aureo-brunneis, apice rotundatis, truncatis v. attenuatis, interdum obliquis, medio leniter constrictis, basi saepius attenuatis, 40-77 $\times 15-25 \mu$ plerumque 15-20 $\mu$ latis; episporio ca. $1.5 \mu$ crasso apice incrassato usque $10 \mu$; pedicello subpersistente, brunneolo, usque $25 \mu$ longo.

Hab. in foliis calamisque $K y$ llingae melanospermae Nees, Donkerpoort, leg. Doidge et Bottomley, 29971 ; II. Karino, leg. Wager, 23414.

This rust differs from Puccinia mysorensis Syd. et Butler [Ann. Myc. 4 (1906), p. 434], in the size of the teleutospores, which are larger and thicker at the apex. The uredo resembles Uredo Kyllingiae P. Henn., but so far as can be ascertained the teleuto-stage of this American species has not been described.

\section{Puccinia schoenoxyphii nov. spec.}

Soris teleutosporiferis sparsis, maculis minutis, brunneis, conspicuis, plerumque ellipticis, usque $2 \mathrm{~mm}$. longis, singulariter insidentibus; soris minutis, ellipticis, $\frac{1}{2}$ to $\frac{3}{4} \mathrm{~mm}$ longis, fusco-brunneis, diu epidermide bullata tectis. Teleutosporis plerumque clavatis, rarius fusoideis v. oblongis, rectis $\mathbf{v}$. leniter curvatis, pallide luteo-auranteis, ad apicem obscurioribus, apice rotundatis rarius recte v. oblique obtuse conicis, medio plus minus contrictis, basi plerumque attenuatis, nonnunquam subrotundatis, $40-58 \times 14-20 \mu$; episporio leve, tenue, $1-1 \cdot 5 \mu$ crasso, ad apicem valde incrassato, $7 \cdot 5-12 \cdot 5 \mu$, interdum usque $15.5 \mu$; pedicello persistente, leniter brunneolo, $5 \mu$ crasso et usque $50 \mu$ longo.

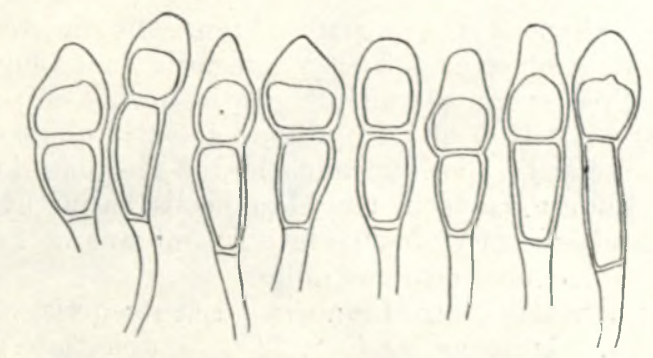

Fig. 11.-Puccinia schoenoxyphii, teleutospores.

Hab. in foliis Schoenoxyphii spartii Kuk., in silvis Xumeni, prope Donnybrook, leg. Morgan et Doidge, 30106.

Puccinia scleriae-dregeanae nov. spec.

Soris uredosporiferis amphigenis, plerumque hypophyllis, maculis minutis, conspicuis, elongatis, usque $1 \mathrm{~mm}$. longis, sparsis insidentibus, singulis v. paucis in quoque macula, ellipticis v. linearibus, cinnamomeis, usque $400 \mu$ longis, diu epidermide bullata tectis. Uredosporis ellipsoideis, ovatis v. subglobosis, 20-30 × 15-20 $\mu$; episporio fere hyalino, $1-1 \cdot 5 \mu$ crasso, remote subtiliterque echinulato, poris germ. obscuris, ut videtur 3 , equatorialibus.

Soris teleutosporiferis inter soros uredosporiferos sparsis, hypophyllis, minutis, 150-200 $\mu$ longis, ellipticis, atro-brunneis, epidermide tectis, compactis. Teleutosporis plerumque clavatis, rarius cylindraceis v. fusoideis, $30-45 \times 10-22 \cdot 5 \mu$, cellula superiore pallide auranteo-brunnea usque cinnamomea, inferiore pallidiore, apice rotundatis, truncatis $\mathrm{v}$. plerumque oblique acuminatis $\mathbf{v}$. melius in rostrum productis, medio non vel vix constrictis, basi plerumque pedicellum versus attenuatis, interdum subrotundatis; episporio leve, tenue, $1-1 \cdot 5 \mu$ crasso, ad apicem leniter incrassato $3 \cdot 5-8 \mu$; pedicello persistente, pallide flavo-brunneolo, $5-6 \mu$ crasso et usque $23 \mu$ longo. 

29982.

Hab. in foliis Scleriae Dregeanae Kunth, Donkerpoort, leg. Doidge et Bottomley,

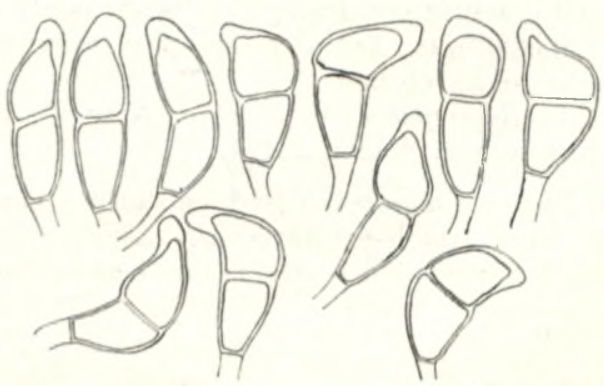

Fig. 12.-Puccinia scleriae-dregeanae, teleutospores.

The loculi separate readily at the septum and fall apart. This rust differs widely from Rostrupia scleriae Pazschke in the size of the teleutospores and sori, and in the absence of 2 -septate spores. It approaches more nearly to Puccinia scleriicola Arthur, but there has been no opportunity of examining this species. The description differs in several details (Mycologia 7, 1915, p. 232) particularly in the almost hyaline uredospores.

\section{Puccinia amphilophidis nov. spec.}

Soris uredosporiferis hypophyllis, maculis brunneolis indeterminatis insidentibus, minutis, usque $\frac{3}{4} \mathrm{~mm}$. longis, oblongis, sparsis v. gregariis, mox nudis, epidermide lacerata cinctis, cinnamomeis. Uredosporis plerumque ovatis, rarius ellipsoideis $\mathbf{v}$. subglobosis, echinulatis, brunneis, 25-35 $\times 17 \cdot 5-20 \mu$; episporio $1 \cdot 5-2 \cdot 5 \mu$ crasso, ad apicem nonnunquam leniter incrassato usque $4 \mu$, poris germinationis 4-6 equatorialibus praedito. Paraphysibus numerosis, capitatis v. clavatis, flavo-brunneolis, rarius hyalinis, rectis v. leniter curvatis, 45-85 $\mu$ longis, ad apicem $12 \cdot 5-20 \mu$ latis, membrana ca $2-2 \cdot 5$ crassa, ad apicem usque $7 \cdot 5 \mu$ incrassata, lumine haud raro fere nullo.

Soris teleutosporiferis consimilis, atro-brunneis. Teleutosporis subglobosis v. oblongoellipsoideis, levibus, castaneo-brunneis, $30-40 \times 22-25 \mu$, apice late rotundatis, basi rotundatis v. subattenuatis, medio vix constrictis ; episporio $2 \cdot 5-3 \mu$ crasso, apice leniter incrassato, usque $6.5 \mu$; pedicello persistente, crassiusculo, apice 5-7.5 $\mu$ crasso, usque $115 \mu$ longo, ubique brunneolo, interdum oblique, rarius lateraliter inserto.

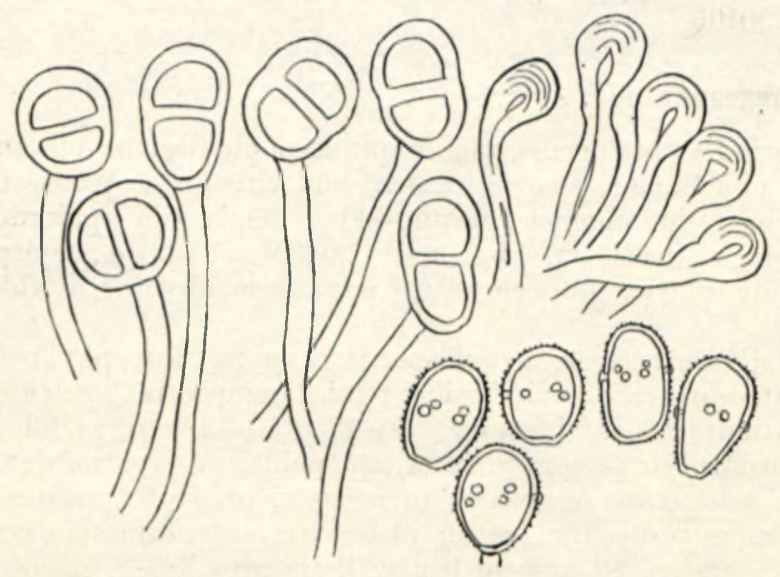

Fig. 13.-Puccinia amphilophidis, teleutospores, paraphyses and uredospores. 
Hab. in foliis Amphilophidis insculptae Stapf., Schagen, leg. Liebenberg, 26024 ; II. Godwan River. leg. Liebenberg, 26056 ; Nelspruit leg. Liebenberg, 26029 ; Warmbaths, leg. Curson, 26394.

This rust resembles Puccinia versicolor and $P$. erythraeënsis, which also occur on Andropogoneae, in the form of its teleutospores, but differs in having brown pedicels. The uredospores differ from those of either of the two species mentioned in having 4-6, fairly conspicuous, sub-papillate, equatorial germ pores.

Puccinia eucomis nov. spec.

Soris uredosporiferis amphigenis, dense seriatim dispositis, oblongis, $\frac{1}{2}-1 \mathrm{~mm}$. longis saepe autem confluendo longioribus, aurantiacis, mox nudis, pulverulentis, epidermide fissa cinctis. Uredosporis plerumque ovatis, rarius subglobosis v. oblongis, $25-35 \mu \times$ 18-22.5 $\mu$; episporio subhyalino, subtiliter verruculoso, $2-2 \cdot 5 \mu$ crasso, ad a picem incrassato 6-7.5 $\mu$, rarius usque $9 \mu$; poris germinationis obscuris; paraphysibus nullis.

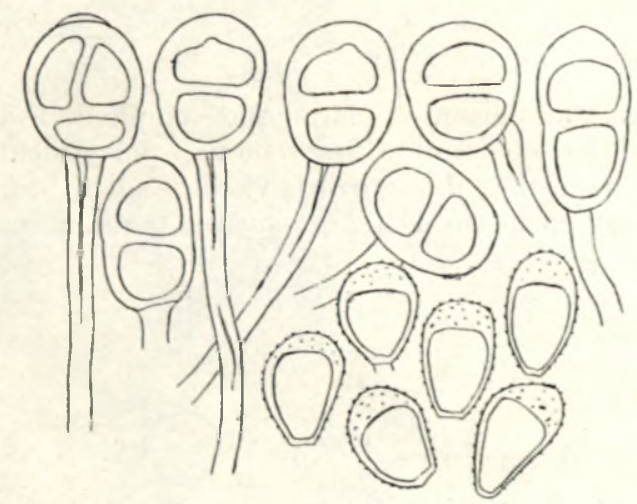

lig. 14.--Puccinia eucomis, teleutospores and uredospores.

Soris teleutosporiferis conformibus, atro-brunneis, subpulvinatis. Teleutosporis castaneis, levibus, plerumque late ellipsoideis, rarius subglobosis v. ovatis, apice late rotundatis, medio haud constrictis, basi rotundatis v. interdum sub-attenuatis, $35-47.5 \times$ 22.5-30 $\mu$; episporio 2.5-3 $\mu$ crasso, apice incrassato usque $9 \mu$, plerumque ca $7 \cdot 5 \mu$ pedicello crasso, persistente, pallide brunneolo, saepe oblique v. transverse inserto, $7 \cdot 5-8 \mu$ crasso et usque $100 \mu$ longo.

Hab. in foliis vaginisque Andropogonis eucomis Nees, Donkerpoort, leg. Doidge et Bottomley, 30129 .

The uredo has also been collected on Andropogon huillensis Rendl. Donkerpoort, Doidge and Bottomky, 30132.

One 3-celled teleutospore was seen. The contents of the uredospores are bright orange, and this gives the orange colour to the uredo-sori.

The teleutospores of the known species of Puccinia on South African Andropogoneae resemble one another very closely; the uredoform is more distinctive, and the species of rust on these hosts may readily be distinguished when uredo-spores are present. The distinguishing characters are indicated in the following key :-

A. Paraphyses present, germ pores conspicuous.

a. Uredo-spore uniformly thin walled, brown, with 5-8, rather conspicuous, scattered germ pores.... Puccinia erythraeënsis. 
b. Wall of uredo-spore thickened at the apex.

$\mathrm{x}$. Apex slightly thickened, up to $4 \mu$, spore $25-35 \times 17 \cdot 5-20 \mu, 4-6$, equatorial germ

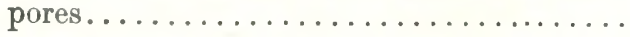

Puccinia amphilophidis.

xx. Apex more definitely thickened, up to $8 \mu$, spore $30-42 \cdot 5 \times 22 \cdot 5-30 \mu, 2-3$ equatorial germ pores................... Uredo schizachyrii.

B. Paraphyses wanting.

a. Germ pores obscure.

x. Wall of uredo-spore thickened irregularly, cavity stellate.................. Puccinia versicolor.

xx. Wall thickened at the apex, up to $9 \ldots \ldots$ Puccinia eucomis.

b. Germ pores evident, 4-7, scattered......... Uromyces Clignyi.

\section{Puccinia Bottomleyae nov. spec.}

Soris uredosporiferis amphigenis, plerumque epiphyllis, oblongis, cinnamomeis, $\frac{1}{2}-\frac{5}{8} \mathrm{~mm}$. longis, mox nudis, epidermide fissa cinctis, pulverulentis. Uredosporis saepe etiam teleutosporis immixtis, sub-globosis, ovatis v. ellipsoideis, brunneis, $22-30 \times 20-25 \mu$, laxe minuteque aculeatis; episporio $1 \cdot 5-2 \mu$ crasso, poris germinationis $4-7$, sparsis instructis.

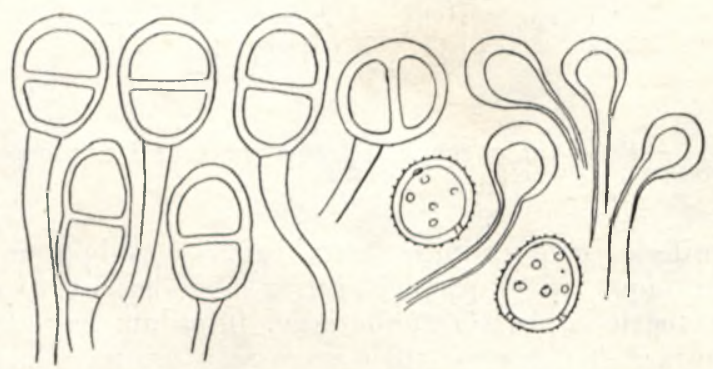

Fig. 15.-Puccinia Bottomleyae, teleutospores, uredospores and paraphyses.

Soris teleutosporiferis conformibus, atro-brunneis. Teleutosporis subglobosis, oblongis v. ovatis, castaneo-brunneis, levibus, apice rotundatis, medio haud constrictis, basi rotundatis v. subattenuatis, $27 \cdot 5-40 \times 20-25 \mu$; episporio $2-2 \cdot 5 \mu$ crasso, apice leniter incrassato, usque $6 \mu$; pedicello persistente, apice brunneolo, 6-6.5 $\mu$ crasso, 85-112.5 $\mu$ longo, nonnumquam oblique inserto. Mesosporis paucis, subglobosis v, ovatis, $25-27.5 \times 22.5 \mu$. Paraphysibus numerosis, capitatis, brunneolis, 50-100 $\mu$ longis; capite 15-20 $\mu$ latis, membrana leve, $1-1 \cdot 5 \mu$ crassa, apice valde incrassata, usque $10 \mu$.

Hab. in foliis Aristidae Welwitschiae Rendl, et A. barbicollis Trin. et Rupr., Derdepoort, leg. Doidge et Bottomley, 29793 et 29795.

Aristida adscensionis Linn., Buffelspoort, Marikana, leg. Doidge, 29991 ; Derdepoort, leg. Doidge et Bottomley, 29790.

Aristida sp., Derdepoort, leg. Doidge et Bottomley, 29789. 
Puccinia digitariae Pole Evans.

in Ann. Bolus Herb. 2 (1917), 111 ; Doidge in Bothalia 2 (1927), 124.

Syn. Uredo digitariaecola Thuem. in Myc. Univ. No. 2041 (1882); Syd. Monogr. Ured. 4 (1924), 604.

The illustration of this rust in Bothalia (loc. cit.) is misleading. The teleutospores are closely crowded in the minute, compact sori and are consequently much more irregular in form than the drawing indicates, especially at the apex. One 3-celled spore was seen, and in several teleutospores, germ pores at the apex and just below the septum were observed. The teleutospores are delicate and very easily crushed.

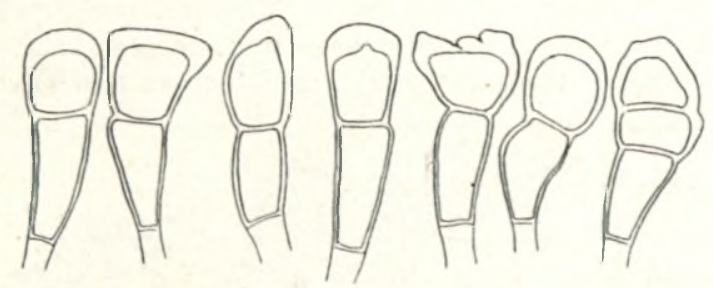

Fig. 16.-Puccinia digitariae, teleutospores.

In addition to the hoste previously recorded, i.e. Digitaria debilis, D. eriantha and D. Smutsii, this rust has been found on :-

Digitaria horizontalis Willd., Nelspruit, Liebenberg, 26649.

Digitaria Pentzii Stent, Donkerpoort, Doidge and Bottomley, 29750, Ashbury, Doidge and Bottomley, 29783.

Digitaria setivalva Stent, Salisbury, Hopkins, Rhod. Myc. Herb., $2 \mathrm{C} 02$ and 2071.

The Rhodesian collection [Hopkins in Trans. Rhod. Sc. Ass. 35 (1938), 106], is designated "Puccinia digitariae affinis". From an examination of a portion of this material kindly supplied by Dr. Hopkins, it appears that this rust is typical Puccinia digitariae.

Puccinia eragrostidis-chalcanthae nov. spec.

Soris teleutosporiferis epiphyllis, oblongis, $0 \cdot 5-2 \cdot 5 \mathrm{~mm}$. longis, sparsis v. aggregatis et confluendo longioribus, mox nudis, brunneis, pulverulentis. Teleutosporis subglobosis v. oblongis, aureo-brunneis, $26-27 \cdot 5 \times 17 \cdot 5-25 \mu$, apice late rotundatis v. obtuse conicis, medio haud constrictis, basi rotundatis; episporio leve, $3-4 \mu$ crasso, apice plerumque incrassato, usque $8 \mu$; pedicello tenue, hyalino, persistente, usque $75 \mu$ longo, ad apicem $5 \mu$ crasso, deorsum attenuato.

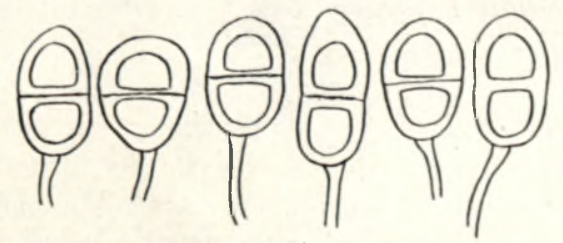

Fig. 17.-Puccinia eragrostidis-chalcanthae, teleutospores. 29760.

Hab. in foliis Eragrostidis chalcanthae Trin., Donkerpoort, leg, Doidge et Bottomley,

Through the courtesy of Dr. Kern and of Dr. Stevenson of the Division of Mycology and Plant Disease Survey, Washington, a portion of the type collection of Puccinia eragrostidicola Kern, Thurston and Whetzel (Mycologia 25, 1933, p. 469) was available for study. The South African rust described above is near this species, but the teleutospores 
are much more variable in form and are thicker walled; the pedicel is hyaline and inserted directly, whereas in $P$. eragrostidicola it is tinted brown and is often oblique. Puccinia eragrostidis Petch (Ann. Roy. Bot. Gard. Peradeniya 6, 1917, pp. 209, 216) has narrower, ovoid or oblong-ovoid teleutospores, 20-32 × 15-17 $\mu$, with hyaline, oblique pedicel.

\section{Puccinia eragrostidis-superbae nov. spec.}

Soris uredosporiferis amphigenis, plerumque hypophyllis, ochraceis, ellipticis v. ollongis, minutis, usque $\frac{1}{2} \mathrm{~mm}$. longis, epidermide fissa cinctis. Uredosporis ovatis, fusco-brunneis, ad apicem obscurioribus, $27-32 \times 17-25 \mu$; episporio $1.5-2 \mu$ crasso, ad apicem saepe leniter incrassato, usque $4 \mu$, sparse valideque echinulato, poris germinationis 4-6, conspicuis, equatorialibus praedito. Paraphysibus satis numerosis, clavatis, rectis v. leniter curvatis, $25-65 \times 8-17.5 \mu$; membrana leve, 1.5-4 $\mu$ crasso, ad apicem incrassato usque $12 \cdot 5 \mu$.

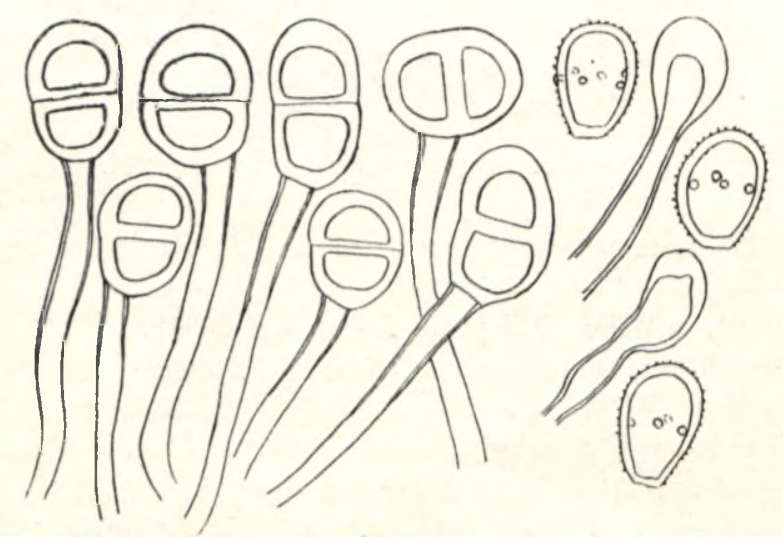

Fig. 18.-Puccinia eragrostidis-superbae, teleutospores, paraphyses and uredospores.

Soris teleutosporiferis amphigenis, plerumque hypophyllis, atro-brunneis, oblongis, $\frac{1}{2}-1 \mathrm{~mm}$. longis, saepe confluendo longioribus, epidermide fissa cinctis. Teleutosporis subglobosis, ovatis $\mathbf{v}$. late ellipsoideis, utrinque rotundatis, medio non vel vix constrictis, 35-45 $\times 25-30 \mu$; episporio leve, castaneo-brunneo, cellula inferiore $3-4 \mu$ crasso, cellula superiore $4-5 \mu$ crasso, ad a picem incrassato $8-10 \mu$; pedicello persistente crasso, ad apicem 8-10 $\mu$ crasso, brunneolo, usque $112 \mu$ longo, membrana crassa.

Hab. in foliis Eragrostidis superbae Peyr., Derdepoort, leg, Doidge et Bottomley, 29811 ; (II) in foliis Eragrostidis happulae Nees var. divaricatae Stapf. Derdepoort, leg. Doidge et Bottomley, 29813.

Puccinia miscanthidii nov. spec.

Soris uredosporiferis hypophyllis, minutis, sparsis, ca. $\frac{1}{2} \mathrm{~mm}$. longis, pulverulentis, luteo-aurantaceis $v$. cinnamomeis. Uredosporis ovatis, oblongis v. subglobosis, pallide aurantiacis deinde brunneis, $24-30 \times 17 \cdot 5-25 \mu$; episporio $1-1 \cdot 5 \mu$ crasso, subtiliter verruculoso, poris germinationis obscuris, ut videtur minutis sparsis.

Soris teleutosporiferis amphigenis, plerumque hypophyllis, sparsis, aggregatis v. seriatim dispositis, $\frac{1}{4}-2 \mathrm{~mm}$. longis, saepe confluendo longioribus, pulvinatis, atro-brunneis, epidermide fissa cinctis. Teleutosporis castaneo-brunneis, apice saepe obscurioribus, oblongis, clavatis, subglobosis v. irregularibus, apice rotundatis v. conicis, rarius truncatis, medio non vel vix constrictis, basi rotundatis v. subattenuatis, 30-50 $\times 20-30 \mu$; episporio leve. $2-2.5 \mu$ crasso, apice incrassato usque $8 \mu$; pedicello crassiusculo, persistente, ubique brunneolo, ca $10 \mu$ crasso, usque $87.5 \mu$ longo, saepe oblique, interdum lateraliter inserto. 


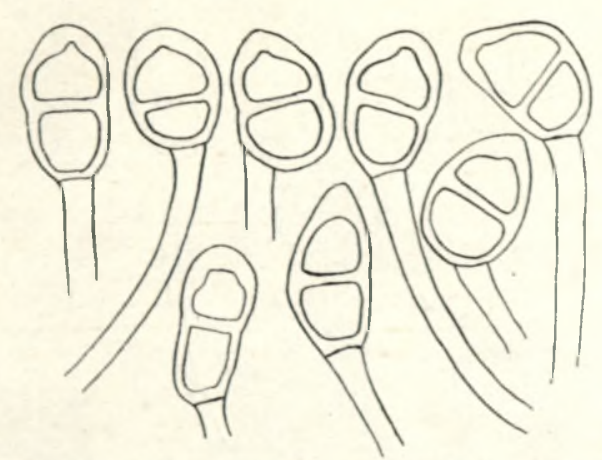

Fig. 19.-Puccinia miscanthidii, teleutospores.

Hab. in foliis Miscanthidii sorghi Rich., Lundie's Hill, Umkomaas Valley, leg, Doidge 30104; in foliis Miscanthidii juncei Stapf., Trigaartspoort, leg. Doidge et Bottomley, 30105 .

This species is closely related to Puccinia imperatae Doidge on Imperata cylindrica Beauv. (Bothalia 2, 1928, p. 474) from which it differs in the colour and form of the teleutospores; they are darker brown, more irregular in form and thinner walled; the pedicel is tinted brown throughout, and is frequently inserted obliquely, occasionally transversely.

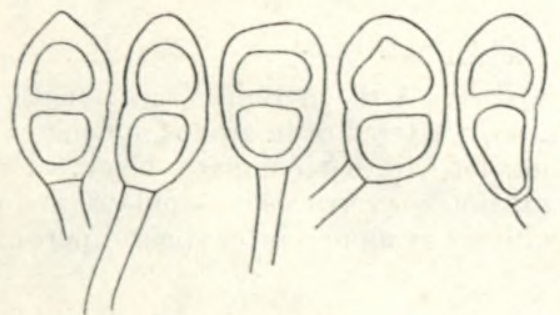

Fig. 20.-Puccinia imperatae, teleutospores.

\section{Puccinia pogonarthriae Hopkins.}

in Trans. Rhod. Sc. Soc. 35 (1938), 106.

Syn. Uredo pogonarthriae Syd. in Ann. Myc. 10 (1912), 35; in Bothalia 2 (1927), 198.

Uredo-sori amphigenous, but mostly hypophyllous, scattered, oblong, $\frac{1}{2}-2 \mathrm{~mm}$. long, surrounded by the torn epidermis, pulverulent, rusty brown. Uredospores globose or subglobose, light brown, $22-26 \times 18-22 \mu$; epispore light golden brown, 1.5-2.5 $\mu$ thick, delicately echinulate and with about six scattered germ pores.

Teleutosori epiphyllous, scattered, oblong, $\frac{1}{2}-2 \mathrm{~mm}$. long, dark brown, surrounded by the torn epidermis, soon becoming pulverulent. Teleutospores subglobose or oblong, broadly rounded or obtusely conical at the apex, not constricted at the septum or very slightly so, rounded at the base, golden brown, 25-40 $\times 17-25 \mu$; epispore smooth, $2 \cdot 5-4 \cdot 5 \mu$ thick, often slightly thickened, up to $8 \mu$, at the apex ; germ pore apical or slightly oblique in the upper cell, one-half to one-third of the distance from septum to base in the lower cell ; pedicel sub-persistent, hyaline, $5 \mu$ thick at the apex, and up $50 \mu$ long.

Hab. on leaves of Pogonarthria squarrosa (Light.) Pilg., Donkerpoort, Doidge and Bottomley, 29757. 


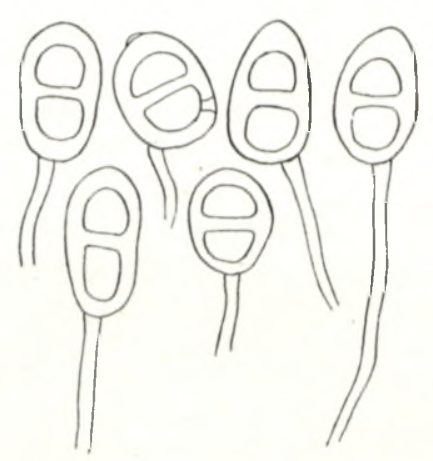

Fig. 21.-Puccinia pogonarthriae, teleutospores.

A portion of the type collection was made available for comparison through the courtesy of Dr. Hopkins. The type was collected on the same host at Marandellas (Rhod. Govt. Myc. Herb., 2163); it is evidently the same species as the rust collected at Donkerpoort but the teleutospores of the latter are more variable in form. The description is amended accordingly. The uredo described by Sydow (loc. cit.) on Pogonarthria squarrosa, was found on the same leaves.

\section{Puccinia luxuriosa Syd.}

in Monogr. Ured. 1 (1904), 812.

Syn. Puccinia tosta var. luxuriosa Arth. in Bull. Torr. Bot. Club 29 (1902), 229.

Teleuto-sori amphigenous, scattered or in groups, oblong or linear, often confluent and forming striae up to $6 \mathrm{~mm}$. long, rather compact, black. Uredospores mixed with the teleutospores, globose or subglobose, verrucoso-echinulate, yellow brown, 22-30 $\mu$ diam.; epispore about $2 \mu$ thick, with six or more scattered germ pores.

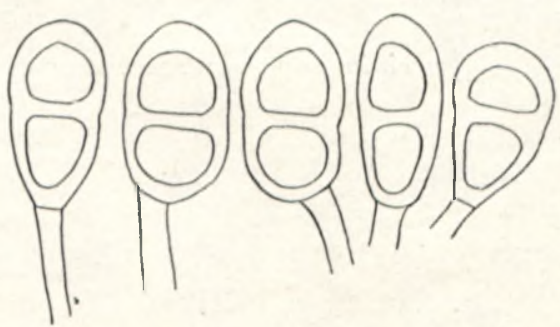

Fig. 22.-Puccinia luxuriosa, teleutospores.

Teleutospores ellipsoid or oblong, rounded at the apex, usually slightly constricted at the septum, usually rounded at the base, brown, $36-56 \times 20-28 \mu$; epispore smooth, 3-5 $\mu$ thick, thickened at the apex, up to $10 \mu$; pedicel stout, persistent, brown at the apex and 7-8 $\mu$ thick, up to $110 \mu$ long. 29726.

Hab. on leaves of Sporobolus pectinatus Hack., Donkerpoort, Doidge and Bottomley,

On Sporobolus capensis (Willd.) Kunth, Donkerpoort, Doidge and Bottomley, 29758.

This rust was originally described on Sporobolus aeroides in Oregon and Montana, North America ; the South African rust agrees well with the description of the American fungus. 


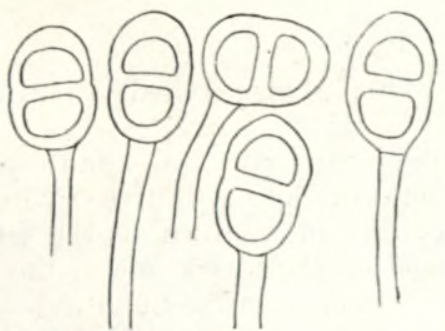

Fig. 23.-Puccinia tosta, teleutospores.

Puccinia luxuriosa differs from $P$. tosta Arthur previously recorded on Sporobolus fimbriatus Nees (Bothalia 2, 1928, p. 474) in the larger and much more conspicuous sori, the echinulate uredospores, and the definitely larger teleutospores. The teleutospores of both species are illustrated for comparison.

\section{Puccinia tristachyae Doidge}

in Bothalia 2 (1927), 132.

The type specimen of this rust was collected at Kaalfontein on Tristachya Rehmami Hack., and the teleutospores were described as follows: "Teleutospores clavate, ellipsoid or oblong, upper cell usually shorter than the lower, rounded or truncate at the apex, rarely subacute, more or less constricted at the septum, attenuate or rounded at the base, golden brown, 40-60 × 16-23 $\mu$; epispore smooth, 1.5-2 $\mu$ thick in the lower cell, $2 \cdot 5-3 \mu$ thick in the upper, rarely very slightly thickened, up to $4 \mu$, at the apex; pedicel persistent, rather stout, light brown, up to $45 \mu$ long and $6.5 \mu$ thick." The first four spores in the figure are typical of those found in the type collection. (See also Bothalia loc. cit.)

Rust pustules on a recent collection of Tristachya hispida K. Schum. are apparently those of the same fungus, but the teleutospores are much more variable than those of the type specimen. A large proportion are typical in form, but comparatively few are $45-55 \mu$ long; the majority are smaller. A large number are irregular in shape, as if through compression; the pedicel is often inserted obliquely and rarely transversely. Mesospores are fairly numerous.

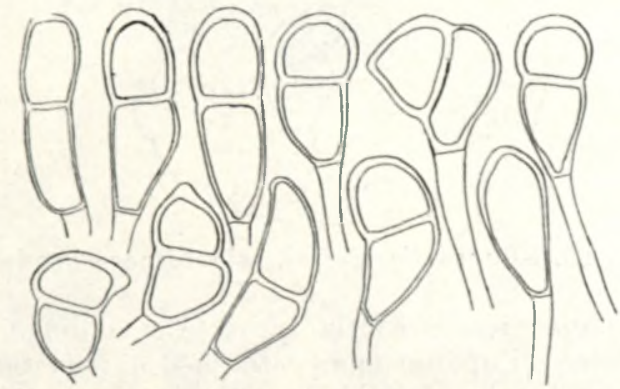

Fig. 24.-Puccinia tristachyae, teleutospores.

There is no doubt that the rust on Tristachya hispida is a more variable form of Puccinia tristachyae, and the description must be amended to include the smaller and more irregular teleutospores found in this collection. It will then read: Teleutospores clavate, ellipsoid, oblong or irregular; upper cell shorter than the lower, or cells sub-equal ; apex rounded, truncate or bluntly conical, in the latter case often oblique ; more or less constricted at the septum, attenuate or rounded at the base, $30-60 \times 15-30 \mu$; a large proportion of the spores do not exceed $40 \mu$ in length; pedicel as previously described, but occasionally oblique and rarely transverse. Mesospores fairly numerous, clavate or cylindrical, $30-53 \times$ $13-17 \cdot 5 \mu$. 30133.

Hab. on leaves Tristachya hispida K. Schum., Donkerpoort, Doidge and Bottomley, 


\section{Ravenelia Evansii Syd.}

in Ann. Myc. 10 (1912), 440 ; Monogr. Ured. 3 (1915), 234 ; Doidge in Bothalia 2 (1927), 144.

Uredo-sori amphigenous, mostly hypophyllous, also on the petioles, subepidermal, minute, round, scattered or in small groups (usually $2-3$ ), $0 \cdot 1-0 \cdot 25 \mathrm{~mm}$. diam., surrounded by the torn epidermis, sub-pulverulent, cinnamon brown, on the same leaflets as the teleuto-sori. (Teleuto-sori are sometimes found on the under side of the leaf, they are not exclusively epiphyllous as the original description might seem to indicate.) Uredospores ellipsoid or ovate, pale yellowish brown, $20-30 \times 12 \cdot 5-15 \mu$, the length being much more variable than the breadth; epispore 1.5-2 $\mu$ thick, occasionally thickened at the apex, up to $5 \mu$, rather closely verruculose-echinulate and with 4 equatorial germ pores. Paraphyses numerous, capitate, yellowish or light brown at the apex, hyaline below, 37.5-50 $\mu$ long, $12 \cdot 5-17 \cdot 5 \mu$ broad.

Hab. on leaves of Acacia robısta Burch., Umzinto, Natal, McClean, 30124.

On Acacia Gerrardi Benth., Verulam, Natal, Halse, 30127.

The type specimen described by Sydow (loc. cit.) showed only the teleuto-sori; the aecidium was subsequently described in Bothalia. A recent collection from the Natal coast has numerous uredo-sori and a few teleuto-sori on the leaves. Uredo- and teleutosori were also found on Acacia Gerrardi, which is a new host for this rust.

\section{Ravenelia Halsei nov. spec.}

Soris teleutosporiferis amphigenis et petiolicolis, plerumque hypophyllis, sparsis, minutis, rotundatis v. ellipticis, $120-300 \mu$ long, cuticula rupta cinctis, obscure brunneis, Capitulis teleutosporarum leniter convexis, ambitu orbicularibus v. suborbicularibus, subtus leniter concavis, castaneo-brunneis, levis, 80-112 $\mu$ diam., ex 9-11 sporis in omni

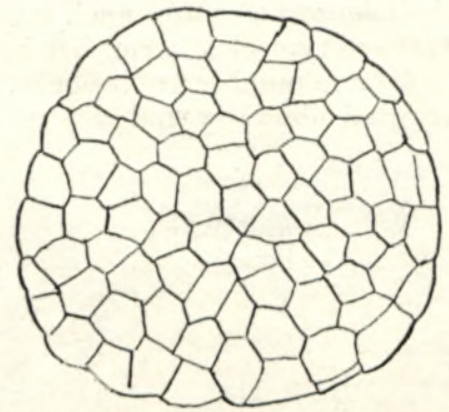

Fig. 25.-Ravenelia Halsei, teleutospore heads.

directione compositis; sporis singulis continuis, recte v. oblique cuneatis vel oblongis, 25-30 $\mu$ longis, $10-15 \mu$ latis, ad apicem incrassatis $(5-6 \mu)$; cystidiis eodem numero quo sporis marginalibus, capitulis dense adpressis, in aqua intumescentibus et tandem ruptis ; pedicello brevi deciduo ex hyphis paucis composito, hyalino.

Hab. in foliis petiolisque Acacine ataxacanthae DC., Ndwedwe, Natal, leg. Halse, 30117.

\section{Ravenelia modesta nov. spec.}

Soris teleutosporiferis subepidermicis, amphigenis v. petiolicolis, plerumque hypophyllis, sparsis, minutis, brunneis, 250-300 $\mu$ diam., Capitulis teleutosporarum convexis, subtus leniter concavis, ambitu orbicularibus, suborbicularibus v. irregularibus, 75-105 $\mu$ diam., aureo-brunneis, ex sporis 5-6 in omini directione compositis ; sporis omnibus papillis 4-7 (plerumque 5) subhyalinis v. brunneolis, 3-5 $\mu$ longis obsitis ; sporis singulis continuis, cuneatis, $27 \cdot 5-45 \mu$ longis, 13-18 $\mu$ latis, ad apicem incrassatis; cystidiis eodem numero quo sporis marginalibus, in aqua intumescentibus; pedicello composito brevi, hyalino. 

30110 .

Hab. in foliis Acaciae stoloniferae Burch., Pienaar's River, leg. Doidge et Bottomley,
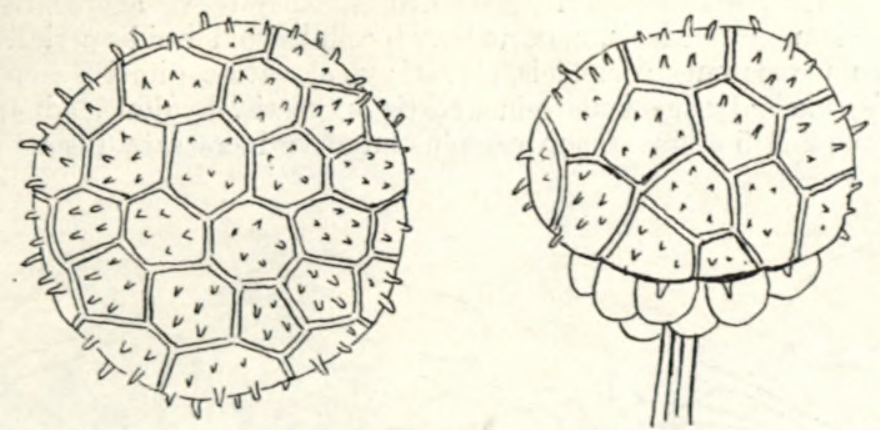

Fig. 26.--Ravenelia modesta, teleutospore heads.

This species is near Ravenelia pretoriensis Syd., but it differs in several particulars. The heads are more definitely convex; the papillae are longer and more conspicuous, acuminate rather than verruciform, straight, oblique or somewhat curved. The sori are very minute; there is frequently only one and rarely more than 2 or 3 on a single leaflet.

Ravenelia pretoriensis Syd.

in Ann. Myc. 10 (1912), 441 ; Doidge in Bothalia 2 (1927), 146.

The host of this rust has been wrongly identified; it is definitely not Acacia horrida Willd. (= Acacia liarroo). The branch and leaf charactere agree well with those of Acacia pennata Willd. and it may be this species; an exact identification is not possible without the pods, which are absent from the material. Further collections will therefore be necessary before the identity of the host can be determined satisfactorily.

In Bothalia (loc. cit.) the drawing of Ravenalia pretoriensis, p. 147, is erroneously labelled $R$. Pienaarii, and under that of $R$. Pienaarii (p. 146) the legend reads $R$. pretoriensis.

Ravenelia transvaalensis nov. spec.

Soris teleutosporiferis amphigenis et petiolicolis; epiphyllis conspicuis, sparsis v. paucis aggregatis, atro-brunneis, rotundatis v. irregularibus, usque $2 \mathrm{~mm}$. diam., epidermide lacerata cinctis; hypophyllis petiolisque inconspicuis, effusis, indeterminatis. Capitulis teleutosporarum convexis, subtus leniter concavis, ambitu orbicularibus, suborbicularibus v. irregularibus, castaneo-brunneis, levibus, 75-100 $\mu$ diam., ex sporis 5-6 in omni directione composito ; sporis singulis 30-35 $\mu$ longis, 15-17.5 $\mu$ latis, ad apicem incrassatis (ca $6 \mu$ ); cystidiis numerosis, ut videtur eodem numero quo sporis singulis, ovatis, dependentibus, in aqua intumescentibus; pedicello non viso.

Hab. in foliis Acaciae detinentis Burch., prope Pienaar's River, leg. Mogg, 27352.
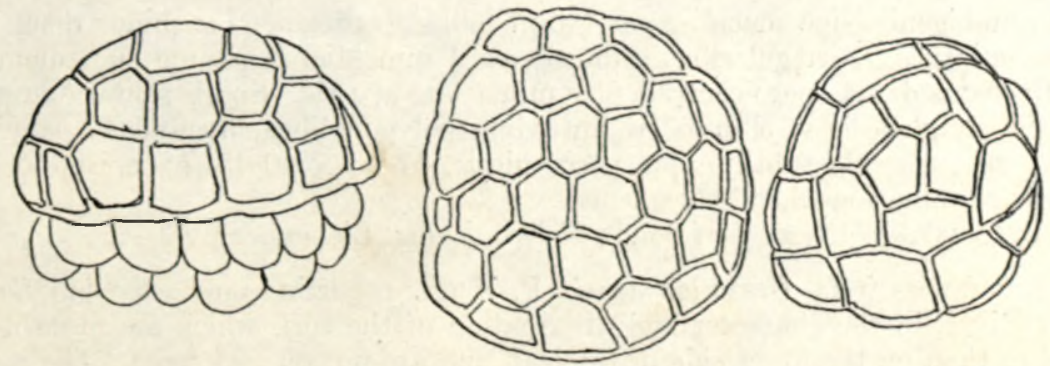

Fig. 27.-Ravenelia transvaalensis, teleutospore heads. 


\section{Uredo Hyperici-leucoptychoides nov. spec.}

Soris hypophyllis, maculis flavis insidentibus, sparsis v. aggregatis, minutissimis, usque $0.2 \mathrm{~mm}$. diam, a urantiacis, mox nudis, ab cellulis epidermidis peridiiformiter cinctis. Paraphysibus numerosissimis, periphicis, clavatis v. clavato-capitatis, saepe irregularibus, 50-100 $\mu$ longis, uncinatis, geniculato-incurvatis $\mathrm{v}$. rectis, hyalinis, ad apicem 10-15 $\mu$ crassis, membrana $2-4 \cdot 5 \mu$ crassa, superne plus minusve incrassata (usque $6 \cdot 5 \mu$ ) lumine

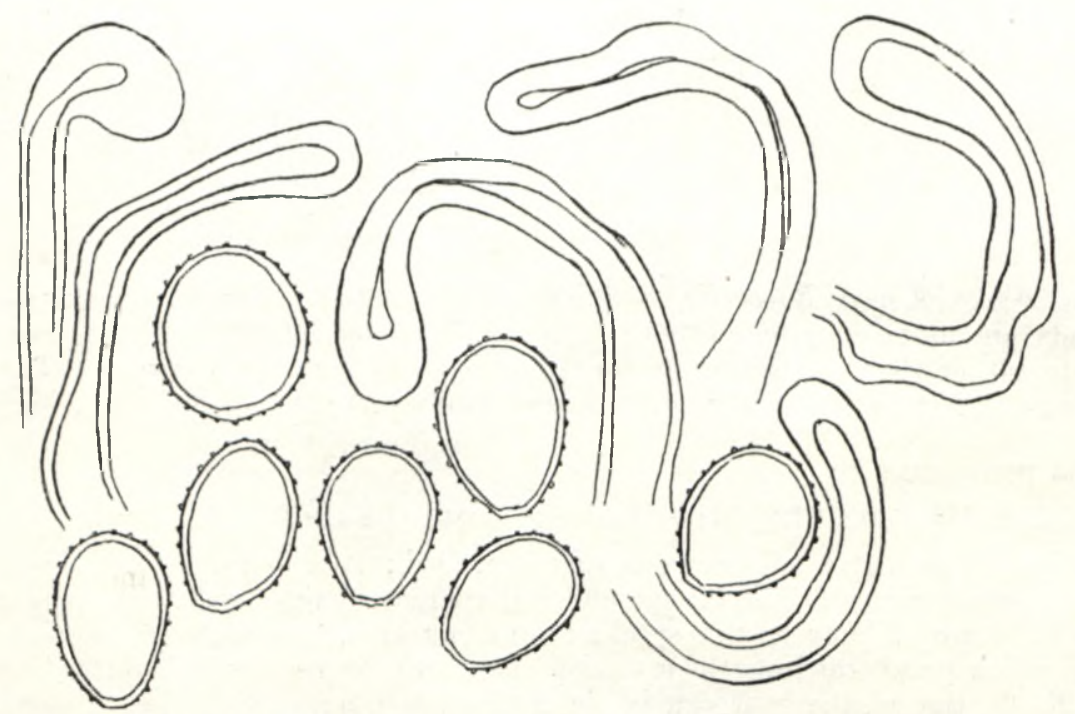

Fig. 28.-Uredo hyperici-leucoptychoides, spores and paraphyses.

haud raro fere nullo. Sporis subglobosis, ovatis v. ellipsoideis, pallide flavo-brunneolis, 17-25 x 15-20 $\mu$, subtiliter laxeque echinulatis, episporio ca $1 \mu$ crasso, poris germinationis haud conspicuis (? 4-7 sparsis).

Hab. in foliis Hyperici leucoptychodis Steud., Woodbush, leg Doidge, 28467.

This rust closely resembles Ureito Hyperici-mysorensis Petch, which occurs in Ceylon, but the paraphyses are longer and stouter. It differs widely from Uredo Hyperici-Schimperi P. Henn. described on Hypericum Schimperi from Central Africa.

\section{Uredo combreticola nov. spec.}

Soris amphigenis, sine maculis, per totam folii superficiem plus minus dense sparsis, rotundatis, ellipticis v. irregularibus, minutis, ca $\frac{1}{4} \mathrm{~mm}$. diam., pallide cinnamomeis, epidermide diu tectis deinde poro centrale plus minus late apertis. Sporis solitarie in pedicellis ortis, ovatis, subglobosis v. ellipsoideis, interdum polygonalibus, hyalinis v. pallide flavobrunneolis, remotiuscule subtiliterque verruculosis, 17-23 $10-15 \mu$; episporio 1-1.5 $\mu$ crasso, poris germinationis haud corspicuis.

Hab. in foliis Combreti Zeyheri Sond., Nelspruit, leg. Liebenberg, 26038.

This rust differs from Uredo longaensis P. Henn. occurring on Combretum Baumii on the Longa River, in the character and distribution of the sori, which are more numerous on the upper than on the lower side of the leaf, and are not on leaf spots. The spores are not in chains as in $U$. longaensis. 
Uredo caricis-petitianae nov. spec.

Soris hypophyllis, maculis brunneolis indeterminatis insidentibus, plus minus aggregatis v. seriatim dispositis, rotundatis v. ellipticis, usque $\frac{1}{2} \mathrm{~mm}$. longis, cinnamomeis, epidermide fissa cinctis. Sporis ellipsoideis, ovatis v. subglobosis, pallide flavobrunneis, laxe verruculosis, $25-30 \times 15-22 \cdot 5 \mu$; episporio $2-2 \cdot 5 \mu$ crasso, poris germinationis $2-3$ equatorialibus praedito.

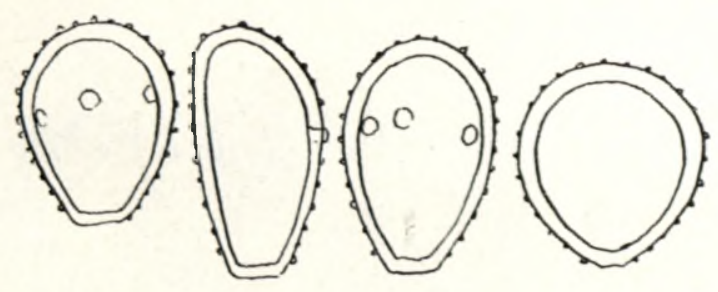

Fig. 29.-Uredo caricis-petitianae, spores.

Hab. in foliis Caricis petitianae A. Rich, in silvis Xumeni, Donnybrook, leg. Morgan et Doidge, $29830,30107$.

The sori are found almost exclusively near the tips of the long leaves; they are on irregular, brown blotches, which are small at first, but increase in size, and finally involve the whole upper portion of the leaf, which becomes brown and dead. Collections were made in winter and in early spring, but no teleuto-sori were found.

Uredo scirpi-corymbosi nov. spec.

Soris calamicolis, maculıs sparsıs ellipticis $1 \cdot \bar{\jmath}-\bar{\tau} \mathrm{mm}$. longis, $1-4 \mathrm{~mm}$. latis, ferrugineobrunneis, tandem plus minus confluentibus insidentibus, solitariis v. paucis parallele aggregatis, linearibus, 2-5 $\mu$ longis, diutissime epidermide elevata tectis. Sporis ovatis, ellipsoideis, subglobosis v. pyriformibus, pallide flavo-brunneis, subtiliter sparseque echinulatis, $27-36 \times 20-25 \mu$; episporio tenue ca $1 \mu$ crasso, poris germinationis obscuris (? 3-4 equatorialibus).

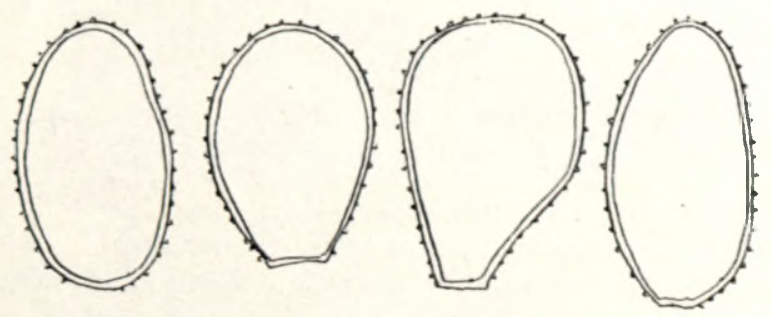

Fig. 30.-Uredo scripi-corymbosi, spores.

Hab. in calamis Scirpi corymbosi Roth., Donkerpoort, leg. Doidge et Bottomely, 29986 ; Skinner's Court, leg. Doidge, 23457 ; Onderstepoort, leg, Pole Evans, 1314 ; Debbe's Ravine, leg. Bottomley, 25332. 
Uredo schizachyrii nov. spec.

Soris amphigenis, minutis, oblongis, ca $\frac{1}{2} \mathrm{~mm}$. longis, epidermide fissa cinctis. Sporis ovatis $\mathrm{v}$. ellipsoideis, apice rotundatis $\mathrm{v}$. obtuse conicis, castaneis, $30-42.5 \times 22 \cdot 5-30 \mu$, crasse sparseque echinulatis; episporio $1 \cdot 5-2 \mu$ crasso, apice incrassato usque $8 \mu$, poris germinationis 2-3 equatorialibus praedito. Paraphysibus numerosis, plerumque capitatis interdum clavatis, $35-62 \cdot 5 \mu$ longis, ad apicem $12 \cdot 5-17 \cdot 5 \mu$ crassis; capite subgloboso brunneolo, membrana leve, valde incrassata $(7 \cdot 5-15 \mu)$ et lamellata.

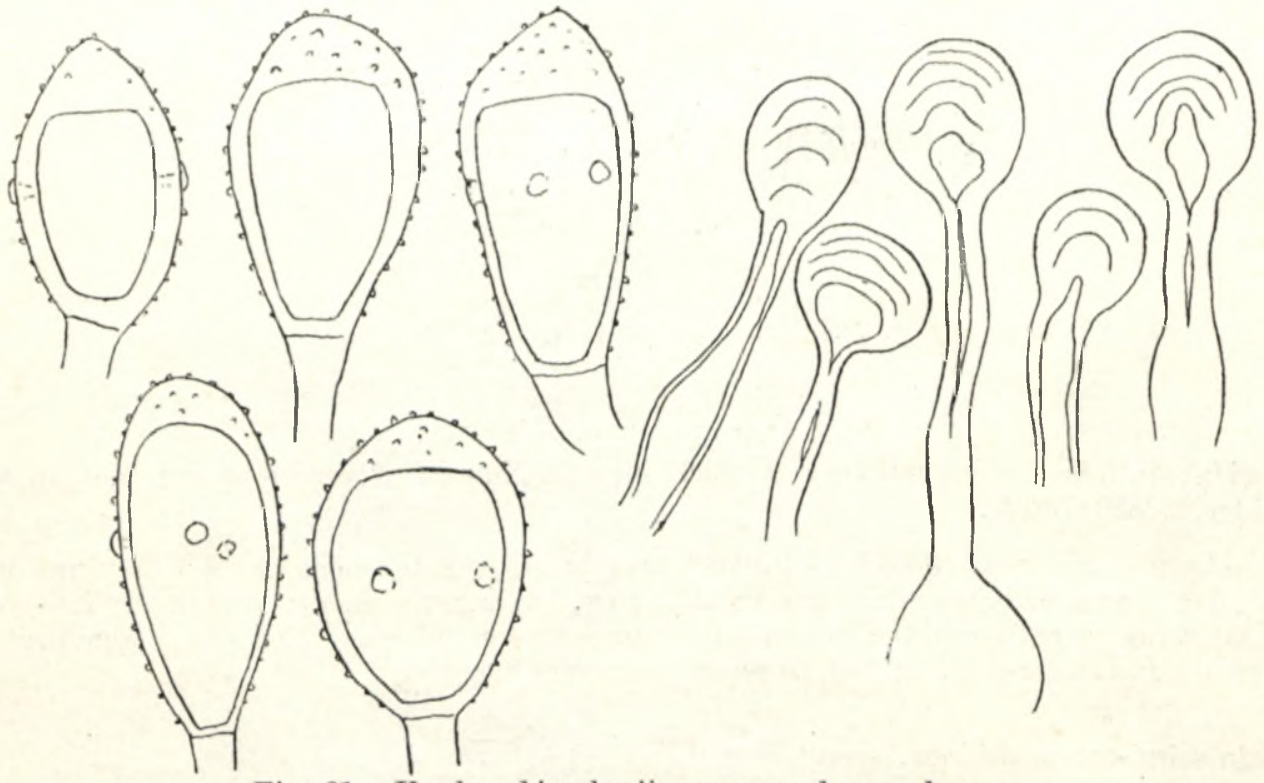

Fig. 31.-Uredo schizachyrii, spores and paraphyses. 29766

Hab. in foliis Schizachyrii semiberbis Nees, Donkerpoort, leg. Doidge et Bottomley,

Uromyces limonii (DC.) Lev.

in Dict. d'Hist. Nat. Art. Uredinees (1840) 19 ; Syd. in Monogr. Ured. 1 (1904) 41.

Syn. Puccinia limonis DC. Fl franc. 2 (1805) 595 et Syn., p. 45.

Aecidium statices Desm. Plant. crypt. de France no. 132.

Aecidium limonii Duby Bot. Gall. 2 (1830) 904.

Caeoma staticis Rudolphi in Linnaea 4 (1829) 510.

Uredo limonii Duby Bot. Gall. 2 (1830) 1897.

(Aecidia amphigenous, often on brown or reddish leaf spots, in round groups, or elongated to $5 \mathrm{~mm}$. long along the veins, usually briefly cylindrical, white, with lacerated margin. Aecidiospores angular-globose or ellipsoid, closely and minutely verruculose yellowish, $21-32 \times 18-26 \mu$.)

Uredo-sori amphigenous, scattered, usually round, oblong on the stems, long covered by the epidermis, at length naked, pulverulent, cinnamon brown. Uredospores globose, subglobose, ovate, ellipsoid or oblong, densely verruculose, yellow brown, 22-32 × 20-28 $\mu$; epispore $1 \cdot 5-2 \cdot 5 \mu$ thick, germ pores $2-3$, scattered.

Teleuto-sori on the leaves and stems ; on the leaves amphigenous, but usually developing more freely on the under surface, scattered or in concentric rings, round or oblong, remaining for some time covered by the blistered epidermis, which finally ruptures and surrounds the 
sorus ; sori pulvinate, dark brown or almost black. Teleutospores golden brown to chestnut brown, subglobose, oblong or clavate, apex broadly rounded or obtusely conical, direct or oblique, base rounded or attenuate, 24-50 × 14-25 $\mu$; epispore smooth, 1.5-2 $\mu$ thick, thickened at the apex up to $10 \mu$; pedicel stout, persistent, tinted brown, $5-6 \mu$ thick at the apex and up to $88 \mu$ long.

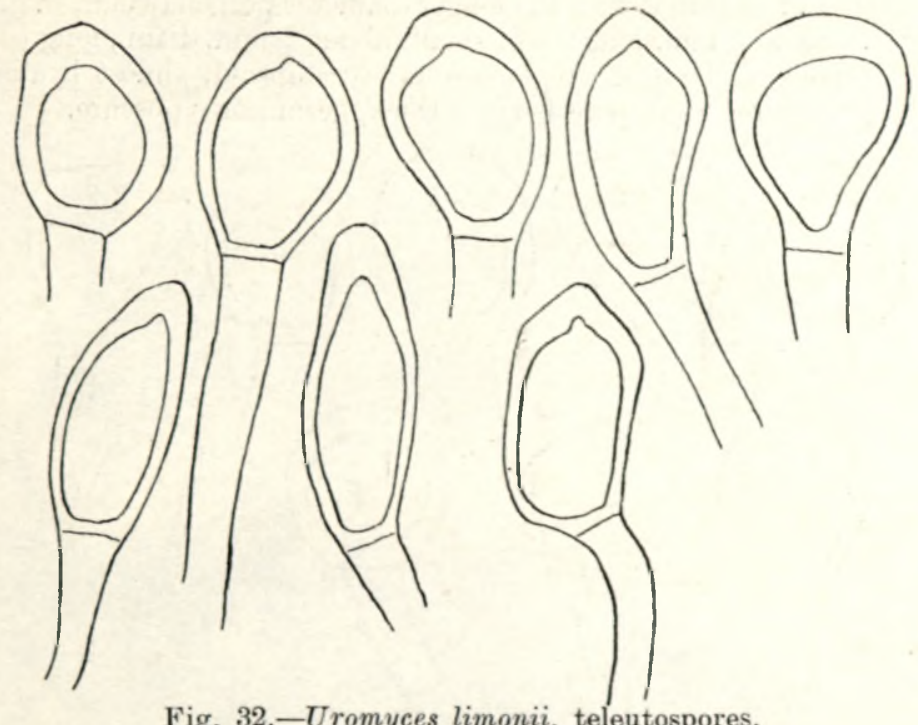

Fig. 32.-Uromyces limonii, teleutospores,

Hab. on leaves of Limonium latifolium Kuntze (= Statice latifolia Sm.), Pretoria, Taylor, 23819 ; Hartebeestpoort, Bottomley.

This rust has not previously been recorded as occurring in South Africa, and has only recently made its appearance in gardens where flowers are grown on a commercial scale. The leaves examined showed a gross infection. Teleutosori were abundant, a few uredospores being found mixed with the teleutospores. No aecidia were seen, the description quoted being that given by Sydow (loc. cit.).

\section{Uromyces Strauchii Doidge}

in Bothalia 2 (1928) 473.

on leaves of Cluytia daphnoides, Alexandria, Doidge, 22370.

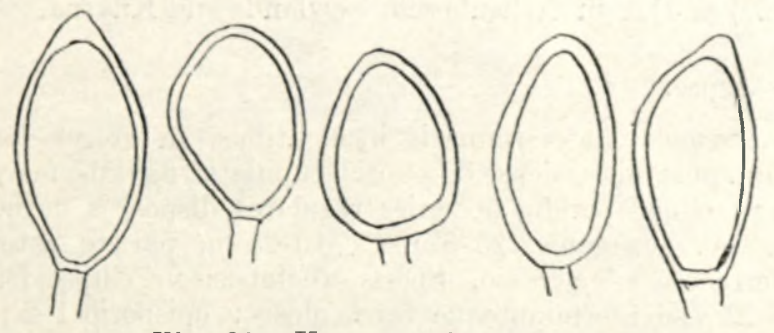

Fig. 33.-Uromyces Strauchii, teleutospores.

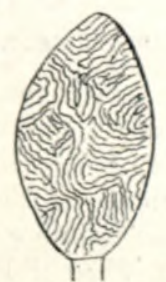

No illustration of this species was published with the original description. Drawings of the teleutospores are reproduced in the accompanying text figure, chiefly to indicate the nature of the sculpturing of the epidermis. 


\section{Uromyces antholyzae Syd.}

in Ann. Myc. 2 (1904) 27 ; Monogr. Ured. 2 (1910) 252.

Uredo-sori amphigenous, not on leaf spots, or on vaguely discoloured areas of the leaf, round or transversely oblong, scattered or in transverse groups between the veins; or caulicolous, scattered or in groups with the longer diameter perpendicular, in groups roughly oval in outline and up to $5 \mathrm{~mm}$. long; sori small, about $\frac{1}{2} \mathrm{~mm}$. diam., long covered by the epidermis. Uredospores globose or subglobose, rarely ellipsoid, almost hyaline, $17 \cdot 5-23 \|$ diam., minutely verruculose ; epispore $1-1 \cdot 5 \mu$ thick, germ pores obscure.

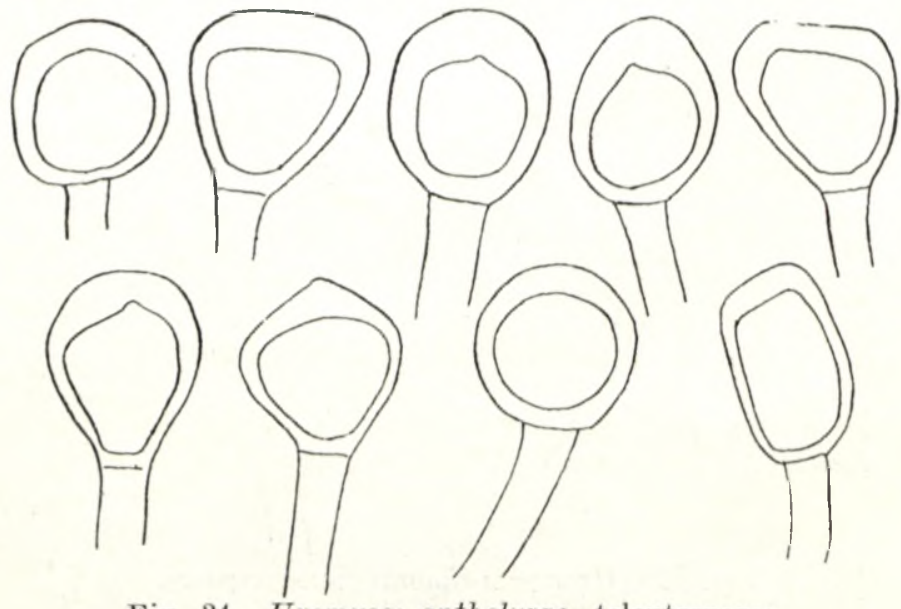

Fig. 34.-Uromyces antholyzae, teleutospores.

Teleuto-sori amphigenous, similar to the uredo-sori but dark brown. Teleutospores subglobose, ovate or oblong, often irregular by compression, brown, $20-25 \times 15-20 \mu$, apex rounded, flattened or obtusely conical ; epispore smooth, 1.5-2 $\mu$ thick, thickened at the apex, 4-7 $\mu$; pedicel persistent, rather stout, light brown, 5-6.5 $\mu$ thick and up to $32 \mu$ long.

Hab. on leaves and stems of Antholyza nervosa Thun. (= Anapalina revoluta N. E. Br.) Ruytersbosch, Mossel Bay, Gemmel (O.F.S. Herb. no. 8053) 30085.

The original description gives wider limits to the size of the teleutospores, otherwise the South African fungus agrees in every detail with the rust collected by Schimper on Antholyza abyssinica in Abyssinia.

This rust has been recorded on the same host by Verwoerd [in Union Department of Agriculture, Bull. 88 (1929) p. 5] from Stellenbosch, Newlands and Knysna.

\section{Uromyces massoniae nov. spec.}

Aecidiis amphigenis, maculis indeterminatis insidentibus, in greges rotundatos, $\mathrm{v}$. elongatos usque $1 \mathrm{~cm}$. diam. plus minus dense dispositis, cupulatis, flavidis, margine revoluto inciso, 300-450 $\mu$ diam.; cellulis peridie in series regulares dispositis, firme conjunctis, subrhomboideis vel penta-v. hexagonis, $25-37.5 \times 15-25 \mu$, pariete exteriore striato 7-10 $\mu$ crasso, interiore verrucoso 4-5 $\mu$ crasso. Sporis subglobosis vel ellipsoideis, plerumque angulatis, $22-27.5 \times 15-22 \mu$, dense minuteque verruculosis ; episporio 1-2 $\mu$ crasso.

Soris uredosporiferis amphigenis, plerumque hypophyllis, sparsis, rotunddatis v. irregulariter rotundatis, epidermide fissa cinctis, pulvervulentis, cinnamomeo-brunneis, usque $1 \mathrm{~mm}$. diam. Uredosporis subglobosis, ovatis v. ellipsoideis, $20-27 \cdot 5 \times 20-25 \mu$, flavis, echinulatis ; episporio $2-2 \cdot 5 \mu$ crasso, poris germinationis pluribus (?4-6) sparsis parum manifestis praeditis. 


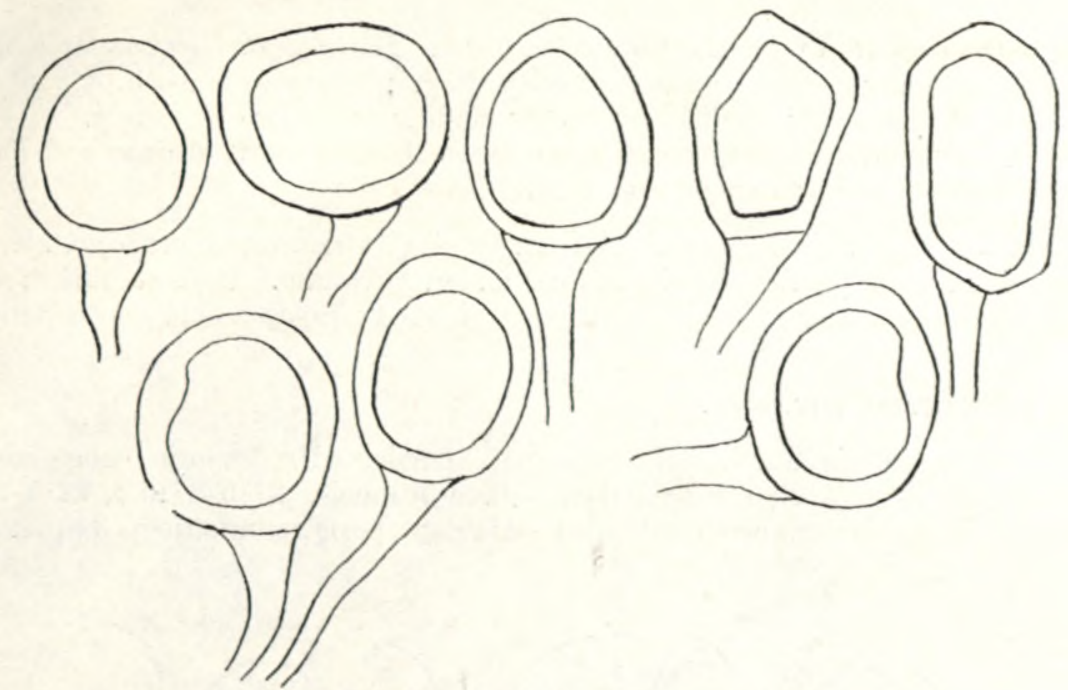

Fig. 35.-Uromyces massoniae, teleutospores.

Soris teleutosporiferis amphigenis circa soros uredosporiferos annulum efficientibus vel sparsis, atris, minutis, diu epidermide tectis. Teleutosporis e mutua pressione quoad formam variabilis, subglobosis, ellipsoideis, pyriformibus, saepe angulatis, castaneobrunneis, levihus, apice rotundatis, $25-32.5 \times 22.5-27.5 \mu$; episporio $3-4.5 \mu$ crasso ; pedicello subpersistente, $15-25 \mu$ longo, apice leniter colorato, 5-7·5 $\mu$ crasso.

Hab. in foliis Massoniae latifoliae Linn. f., Fauresmith, leg. van der Plank, 25447.

Uromyces eriospermi Kalch. et Cke. affinis.

\section{Uromyces Clignyi Pat. et Har.}

in Journ. de Bot. 14 (1900) 237 ; Syd. Monogr. Ured. 3 (1910) 320.

Uredo-sori hypophyllous, scattered, often in series, but rarely confluent, minute, oblong' up to $1 \mathrm{~mm}$. in length, long covered by the epidermis, yellow brown. Uredospores globose or subglobose, golden brown, echinulate, $22-30 \mu$ diam. ; epispore $2-2 \cdot 5 \mu$ thick with 4-7 small, scattered germ pores.

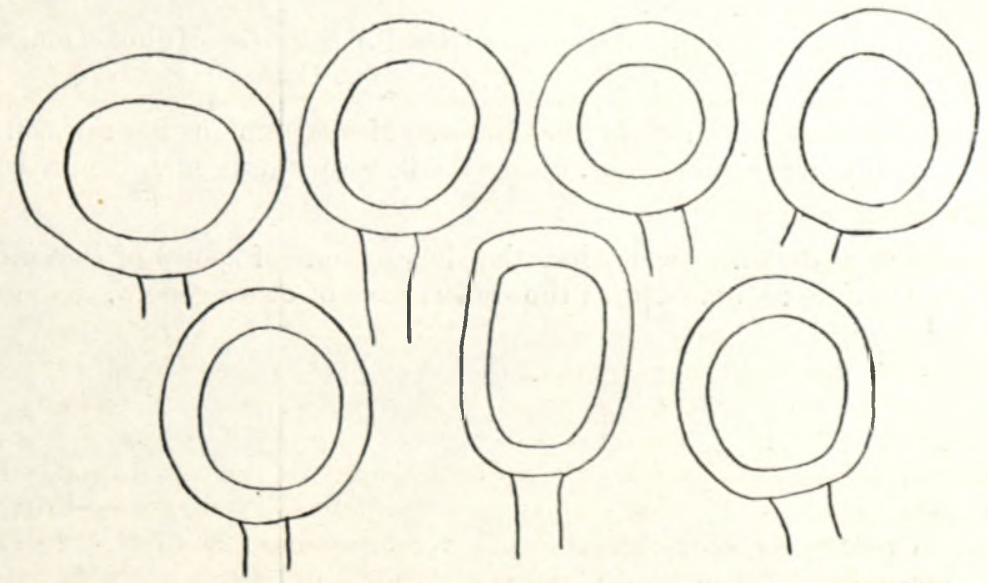

Fig. 36.-Uromyces Clignyi, teleutospores. 
Teleuto-sori similar in form, dark brown to black. Teleutospores globose or subglobose, dark brown, becoming almost opaque, 22-32 $\mu$ diam. ; epispore smooth, 4.5-6 $\mu$ thick, not thickened at the apex; pedicel hyaline, equalling the spore or longer.

Hab. on leaves of Andropogon amplectens Nees, Donkerpoort, Doidge and Bottomley, 29751 ; Derdepoort, Doidge and Bottomley, 29788.

This species was originally described from tropical Africa on Andropogon sp., and on A. multinervis in the region of the river Niger and in Abyssinia. It also occurs in America. Uromyces Clignyi has not previously been recorded on Andropogon spp. South Africa.

Uromyces trichoneurae nov. spec.

Soris uredosporiferis amphigenis, minutis, sparsis. Uredosporis subglobosis, late ellipsoideis v. ovoideis, saepe subangulatis, flavo-brunneis, $27.5-37.5 \times 22.5-27.5 \mu$; episporio 1-1.5 ". crasso, brunneolo, subtiliter echinulato, poris germinationis 3 equatorialibus praeditis.
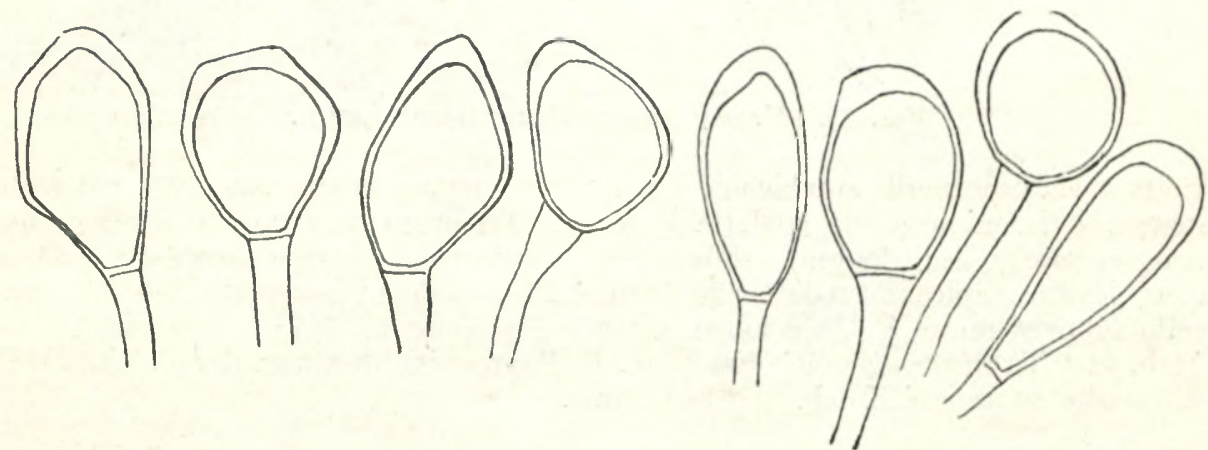

Fig. 37.-Uromyces trichoneurae, teleutospores.

Soris teleutosporiferis plerumque epiphyllis, minutis, usque $\frac{1}{2} \mathrm{~mm}$. longis, interdum confluendo hinc inde majoribus, usque $3 \mathrm{~mm}$. longis. Teleutosporis quoad formam variabilis, subglobosis, ovatis, oblongis $\mathrm{v}$. piriformibus, saepe angulatis, $20-35 \times 16-19 \mu$. apice rotundatis, truncatis $\mathrm{v}$. conicis, basi rotundatis $\mathrm{v}$. attenuatis; episporio leve, $1-1 \cdot 5 \mu$ crasso, apice incrassato usque $5 \mu$; pedicello subpersistente, crassiusculo, apice brunneolo, circ. $5 \mu$ crasso et usque $35 \mu$ longo.

Hab. in foliis Trichoneurae grandiglumis (Rendl.) Stapf et Hubb., Donkerpoort, leg. Doidge et Bottomley, 29762 ; Derdepoort, leg. Doidge et Bottomley, 29792.

I am indebted to the botanists in the National Herbarium for the revision of the host plants, and in particular to Miss L. C. Chippendall, who kindly identified a large number of grasses.

Text figures were drawn to scale, but the illustrations of spores of Puccinia spp. have been reduced by half as compared with those of species of other genera. 